\title{
LAS FUENTES ROMANAS DEL CONCEPTO DE DOMINIO EN EL CÓdIGO CIVIL CHILENO
}

[The Roman Sources of the Concept of Dominium in the Chilean Civil Code]

\section{Cristián AEdo BarrenA*}

\section{RESUMEN}

El presente artículo plantea una revisión del concepto de dominio de nuestro artículo 582 del Código civil, para determinar aquello que pertenece a la tradición jurídica romana en dicha definición y aquello que ha sido aportado por el Derecho moderno. En esta línea, el artículo plantea que el contenido del dominio, como derecho de exclusión de la posesión, sigue permaneciendo en la esencia de la definición de nuestro Código (y no como la pura suma de facultades), pero que no puede considerarse, por el contrario, que se recogiera desde el Derecho romano la idea de que la propiedad fuese un verdadero derecho subjetivo.

Palabras clave jetivo.

\section{ABSTRACT}

This article presents a review of our domain concept Article 582 of the Civil Code, to determine what belongs to the Roman legal tradition within that definition and that which has been provided by the modern law. In this line, the article argues that the contents of the domain, such as exclusion of the right of possession, still remains at the core of the definition of our code (and not the pure sum of powers), but can not be considered, by instead, they pick from Roman law the idea that the property was a real subjective right.

\section{KeYWORDS}

Domain - possession - subjective right.

RECIBIDO el 2 de abril y ACEPTADO el 15 de mayo de 2016

* Doctor en Derecho por la Universidad de Deusto. Profesor de Derecho romano y civil en la Universidad Católica del Norte. Correo electrónico: caedo@ucn.cl. 


\section{LO NUEVO Y LO ANTIGUO EN EL CONCEPTO DE DOMINIO:}

El artículo 582 del CC define el dominio de la siguiente manera: " $E l$ dominio (que se llama también propiedad) es el derecho real en una cosa corporal, para gozar y disponer de ella arbitrariamente; no siendo contra la ley o el derecho ajeno". ¿Cuáles son las bases romanas de esta definición? $\mathrm{O}$, en otras palabras, ¿qué es lo nuevo y lo propiamente romano que aún conserva la definición chilena?

Consideramos que la cuestión puede ser analizada desde dos puntos de vista. Por un lado, uno podría considerar la definición dogmática del dominio. Veamos algunos ejemplos. Alessandri y Somarriva definen el dominio como el derecho que confiere al sujeto el poder más amplio sobre una cosa; en principio, que lo faculta para apropiarse, en forma exclusiva, de todas las utilidades que el bien es capaz de proporcionar. Hay, expuestas por estos autores, toda una discusión relativa a la relación dominio y propiedad y en relación con los tipos de definiciones: unas analíticas, como las sumas de facultades del sujeto (es decir, como aquella contenida en la propia definición del Código civil). Frente a ellas, las cualitativas, intentan dar un concepto unitario del dominio. Se dice, en tal sentido, que dominio es un derecho unitario y abstracto, siempre igual y distinto de sus facultades. ${ }^{2}$

No es esa la óptica que deseamos adoptar aquí, especialmente porque nuestro interés es determinar aquello que la definición recoge del Derecho romano. Pero además porque consideramos que a partir de la definición hay dos aspectos interesantes que pueden ser abordados. En verdad, la definición nos dice dos cosas. En primer lugar, nos indica que el dominio es un derecho real, en otros términos, un derecho subjetivo. En segundo lugar, lo describe como una cosa (porque el derecho es una cosa incorporal) que recae sobre otra cosa (corporal), en función de ciertas facultades, que el

${ }^{1}$ Sobre el origen de la definición de propiedad de nuestro Código, remitimos al trabajo del profesor Amunátegui Perelló, Carlos, No siendo contra derecho ajeno: hacia la formulación de una teoria de las inmisiones en nuestro Código Civil, en Revista Chilena del Derecho, vol. 36, No 3 (2009), pp. 507-510. Véase también, AmUnÁteGUI Perelló, Carlos, Las relaciones de vecindad y la teoría de las inmisiones en el Código Civil, en Revista de Derecho de la Pontificia Universidad Católica de Valparaíso, vol. XXXVIII (2012), pp. 81-89.

2 Alessandri R., Arturo, Somarriva U., Manuel y Vodanovic H., Antonio, Tratado de los derechos reales, t. I: Bienes (Santiago, Editorial Temis-Editorial Jurídica de Chile, 2001), pp. 35-36. Véase, en el mismo sentido, Peñailillo Arévalo, Daniel, Los bienes. La propiedad y otros derechos reales (reimpresión $1^{\text {a }}$ edición, Santiago, Editorial Jurídica de Chile, 2010), p. 77. 
Código menciona como de gozar y disponer. Y, para completar este panorama, deberíamos atender al artículo 583: "Sobre las cosas incorporales hay también una especie de propiedad. Asi, el usufructuario tiene la propiedad de su derecho de usufructo". Entonces creemos que, desde el Derecho romano, uno puede hacerse dos órdenes de preguntas, a) ¿pensaron los romanos en el dominio y, de modo más general, en las potestades como derechos subjetivos?; b) ¿es el dominio una cosa para los romanos?, ¿qué tipo de cosa es?, ¿cuál es su esencia?, ¿coincide con la expresión del Código civil?

Por tanto, consideramos que pueden analizarse tres cuestiones distintas: primero, un panorama acerca del origen y evolución del dominium en Roma; en segundo y tercer lugar, intentar unas respuestas a estos dos órdenes de preguntas que nos hemos formulado.

\section{EL ORIGEN DEL DOMINIUM: LAS POTESTADES DEL PATER}

\section{FAMILIAS}

Si queremos estudiar los orígenes del dominium en Roma, es necesario volver la mirada al origen de la sociedad romana, al denominado período arcaico, y, en este sentido, muchos autores proponen que hay que volver la vista a los poderes del pater familias y a las relaciones jurídicas que giraron en torno a la familia. Las cuestiones sucesorias y la propiedad eran los problemas jurídicos que se les presentaron a los antiguos romanos, en una sociedad de carácter elementalmente rural. ${ }^{3}$ La familia representaba una unidad, por sobre todo, religiosa, agrupados en torno a los antepasados comunes (sacrae familiaria). También se presentaba como una unidad económica, que se dedicaba a la explotación de los bienes familiares (mancipi: el inmueble familiar, el huerto, los animales de tiro y carga; $y$, los esclavos). El pater familias era el varón jefe de la familia. Era el único que detentaba capacidad jurídica, poder de mando y dominium. La familia era, así, una institución a favor del padre. Sólo el cristianismo sentó el principio de que la familia está a favor de los hijos. ${ }^{4}$

A diferencia de la obligatio, como indica Betti, los orígenes del dominio se encuentran en el ámbito de las relaciones familiares; la obligación, en cambio, no era un vínculo entre sujetos de la misma familia, sino necesariamente entre extraños; por el contrario, agrega, las relaciones de la familia

${ }^{3}$ Zimmermann, Reinhard, The law of obligations. Roman Foundations of the Civilian Tradition (Oxford, Clarendon Paperbacks, 1996), pp. 1-3.

${ }^{4}$ Como ocurre con la mayoría de las instituciones jurídicas, es muy controvertido el significado de la familia en Roma. Una excelente explicación de estas teorías se encuentra en Amunátegui Perello, Carlos, Origen de los poderes del pater familias. El pater familias y la patria potestas (Madrid, Dykinson, 2009), pp. 25-29. 
estuvieron circunscritas a la patria potestas y a la manus. En consecuencia, el origen del concepto se encuentra tanto en los poderes que tenía el pater sobre los bienes mancipi, como sobre los sujetos que se encontraban dentro de su familia. ${ }^{5}$ La potestad del pater sobre estos bienes y personas estaba amparada por la vindicatio.

Como se sabe, los bienes mancipi eran aquellos que, según los romanos, tenían carácter más permanente, propio de una sociedad agraria, frente a aquellos que estaban sujetos a cambio (bienes nec mancipi), ${ }^{6}$ no obstante, no ha podido dejar de apuntarse el carácter arbitrario de esta distinción, que aunque muy antigua, fue mantenida por los juristas por respeto a la tradición; ${ }^{7}$ con todo, en el período clásico, como apunta Guzmán Brito, las cosas mancipi corresponderán a un número cerrado. ${ }^{8}$ En efecto, Gayo 3, 14a nos dice que son cosas mancipables: los fundos itálicos y sus edificios, los esclavos y animales que: "suelen ser domados por el cuello o el lomo" (bueyes, caballos, mulos y asnos); las servidumbres de predios rústicos itálicos. Todas las demás cosas son, por tanto, bienes nec mancipi. Y, Gayo afirma que, del mismo modo, "quae incoporalia sunt, nec mancipi sunt exceptis seruitutibus praedorium rusticorum; nam eas mancipi esse constat, quamuis sint ex numero rerum incoporalium", es decir, que las cosas incorporales son por lo general nec mancipi, salvo la servidumbre de predio rústico (Gayo 3, 17). ${ }^{9}$

Dejemos hasta acá la cuestión de la más importante clasificación de los bienes, para detenernos en su importancia. Como sabemos, los bienes mancipi, a diferencia de los nec mancipi, podían ser transferidos sólo en

5 BetTI, Emilio, La Struttura dell'obbligazione romana e il problema de la sua genesi (Milano, Giuffrè, 1955), pp. 55; 91. Indica Betti: "Se poi si attribuice importanza decisiva al sintomo che si desume il carattere necesariamente interfamiliare del "vinculum iuris", siccome rapporto che non può costituirsi all'interno di una famiglia romana ma solo all'esterno della famiglia, fra il paterfamilias e persona estranea all'organismo familiare".

${ }^{6}$ Esta es la explicación que ofrece D'Ors, Álvaro, Derecho Privado Romano (4a edición revisada, Pamplona, Eunsa, 1981), p. 182. Esta misma opinión expresa GuZmán Brito, Alejandro, Derecho Privado Romano (2a edición, Santiago de Chile, Thomson Reuters, 2013), pp. 482-483, que parece ser generalmente acogida en la romanística. Véase también García Garrido, Manuel Jesús, Derecho Privado Romano, t. I: Instituciones (14a edición, Madrid, Ediciones Académicas, 2005), p. 144.

7 Véase Schulz, Fritz, Derecho romano clásico (trad. de José Santa Cruz Tegeiro, Barcelona, Bosh, 1960), p. 333.

${ }^{8}$ GuZMán Brito, cit. (n. 6) p. 482.

${ }^{9}$ La prueba de que se había respetado exclusivamente la tradición se encuentra, a nuestro juicio, en Gayo 3,16, puesto que, aunque camellos y elefantes podían ser animales que solían ser domados, éstos afirma Gayo, no se conocían al tiempo en que la distinción fue practicada y, por tanto, se consideran no mancipables. 
virtud de mancipatio o in iure cesio; en cambio, los bienes nec mancipi admitían la simple traditio (Gayo 3, 19, 20, 21, 22 y 23). ${ }^{10}$

Vamos a centrarnos particularmente en la mancipatio, que nos permitirá explorar el origen del dominio romano. Como ya hemos advertido, la institución fue empleada en un período arcaico de modo general: se trataba, en efecto, de un antiguo acto jurídico, cuyas finalidades fueron, además de la transferencia de un bien mancipi: a) la venta de un hijo in mancipium; b) la adquisición de la mujer, como consecuencia de la coemptio; c) la venta del deudor para el cumplimiento de una obligación, de modo que se le asocia al nexum; d) la liberación del deudor, entre otros empleos. Por ello, Gayo trata sistemáticamente la mancipatio en el libro primero, relativo a las personas y no en el libro segundo (cosas), en el que se limita a decir, en Gayo 2, 23: "Sed mancipatio quidem quemadmodum fiat, suoperiore comentario tradidimus" ("Respecto al modo en que se hace la mancipación, ya tratamos en el anterior Comentario").

De este modo, la mancipatio obedece o se nos presenta asociada a los amplios poderes del pater familia sobre las personas que pertenecen a su grupo familiar y a los bienes que componen el patrimonio de relevancia para el gentilicio, en una sociedad de carácter agrícola, el que incluso se extiende a sujetos libres. Así, en la idea de Bonfante, el fundamento de la distinción entre bienes mancipi y nec mancipi, radica en la mayor importancia para la economía colectiva (gentilicia) de los bienes propios de una sociedad agraria. ${ }^{11}$ De Visccher ha identificado la mancipatio directamente como el modo de transferir las cosas y personas sujetas al poder soberano del pater familias. ${ }^{12}$

Por tanto, lo que nos parece más significativo, es que incluso alcanza a sujetos o personas que no tienen directa relación con la familia. Ello quiere decir, siguiendo el pensamiento de Bonfante, que el concepto de dominio romano tiene un importante componente político, no sólo económico. Como explica Miceli, la tesis de Bonfante pone de manifiesto que en tema de propiedad: "ha in sé degli elementi che la differenziano dai diritti solo eco-

${ }^{10}$ Aún así, tomemos nota de que, por un lado, la cesión ante el magistrado (in iure cesio), podía comprender tanto bienes mancipi, como nec mancipi y, correlativamente, la traditio también fue empleada para la transferencia de bienes mancipi (claro que sólo transfirió la propiedad quiritaria en el caso de capacidad del adquirente). Véase, en este sentido, Schulz, cit. (n. 7) pp. 335-337. García Garrido, cit. (n. 6), pp. $177 ; 181$.

${ }^{11}$ Véase Bonfante, Pietro, Corso di Diritto Romano, t. II: la proprietà (Milano, Giuffrè, 1966), pp. 253 y ss. También véase CAPOgrossi Colognesi, Luigi, Proprietà (dir rom.), en Enciclopedia del Diritto, (Milano, Giuffrè, 1988), t. XXXVII, p. 163.

12 De Visscher, Fernand, "Mancipium" et "res mancipi", en SDHI, 2, (1936), pp. 213 ss. 
nomicamente valutabili, e che necessitano di ulteriori valutazioni di carattere patrimoniale, che si legano non solo all'aspetto potestativo tra il propietario e la cosa, ma anche al rapporto pertinenziale tra la cosa ed il suo titolare." ${ }^{13}$

Hemos dicho que una primitiva concepción del dominio se encontraría en la familia, por oposición a la relación entre sujetos iguales (libres), propia de la obligación. Aun así, el nexum constituye un caso especial, siempre que consideremos que el origen de la obligación se encuentra allí. Gayo nos recuerda, en 2,27, que existe una profunda equivalencia entre nexum y mancipatio, "solum italicum mancipi est, provinciale nec mancipi est. Aliter enim veteri lingua <actu vocatur et quod illis nexus idem nobis est $>$ mancipa $<$ tio>”, es decir: "que los fundos itálicos son mancipables y los provinciales no son mancipables, ya que en el lenguaje arcaico se llama nexum al acto que nosotros llamamos mancipación". ${ }^{14}$

Pero seguimos con la idea central. Siguiendo a Max Kaser, la propiedad romana arcaica constituye un aspecto parcial de la soberanía que corresponde al pater familias en el ámbito de su casa sobre personas (patria potestas, manus) y cosas. Aunque en este período no hay un nombre que designe específicamente el poder sobre las cosas, dicho poder alcanzará todos los objetos de la domus. Kaser, a quien seguimos en esta parte, intenta una explicación para la ausencia de un concepto unitario de las relaciones que más tarde se reunieron en el dominium. El argumento fundamental, según Kaser, se encuentra en la naturaleza de la propiedad arcaica. Según el autor,

${ }^{13}$ Miceli, Maria, Spunti di riflessione storica sul concetto di proprietà: elementi di continuità e discontinuità, en RuSSO RugGERI, Carmela (a cura di), Studi in onore di Antonino Metro (Milano, Giuffrè, 2010), t. IV, pp. 251-252.

${ }^{14}$ Del nexum, se sabe que se trata de un arcaico negocio, que ha llegado hasta nuestros días por referencias imprecisas. La única fuente jurídica, fuera de discusión, se encuentra en las XII Tablas, VI.1: "cum nexum faciet mancipiumve, uti lingua nuncupassit ita jus esto". Las otras referencias son indirectas. Varron se refiere al nexum, citando a Quinto Mucio Scevola y a Manlio. Sobre el tema, por todos, NoAilles, Pierre, Nexum, en Revue Historique de Droit Français et Étranger, № 20-21 (19401941), p. 206. Sobre las dificultades para arrojar luz sobre la institución, véase también la concisa explicación de Grosso, Giuseppe, Nexum (e nexus), en El mismo, Scritti storico giuridici, t. III: Diritto Privato, persone, obbligazioni, succesioni (Torino, Giappichelli, 2001), pp. 510-511. 
Gayo 2, 157; $;^{15}$ Paulo, en D. 28, 2, 11, ${ }^{16}$ confirmado por el tratamiento del denominado consortio ercto non cito (Gayo 3, 154, a-b), ${ }^{17}$ probarían que, en época primitiva, no existía propiedad individual, sino que los bienes pertenecerían a lo que Kaser denomina la comunidad doméstica

15 Según Gayo 2, 157: "Se sui quidem heredes ideo appellantu, quia domestici sunt et uiuo quoque parente quodam modo domini existimantur; unde etiam si quis intestatus mortuus sit, prima causa est in successione liberorum. Necessarii uero dicuntur, quia omni modo, perinde ab intestato quam ex testamento heredes funt". ("Se Ilaman herederos de propio derecho porque son de la familia, y en vida de su padre se consideran en cierto modo segundos dueños; de ahi, si alguien murió intestado, son llamados los descendientes a suceder el primer lugar. Y se llaman necesarios porque en cualquier caso se hacen herederos de la misma manera, tanto abintestato, como por testamento").

16 "In suis heredibus evidentius apparet continuationem dominii eo rem perducere, ut nulla videatur hereditas fuisse, quasi olim hi domini essent, qui etiam vivo patre quodammodo domini existinantur. Unde etiam filius familias appellatur sicut pater familias, sola nota hae adiecta, per quam distinguitur genitor ab eo qui genitus sit. itaque post mortem patris non hereditatem percipere videntur, sed magis liberam bonorum administrationem consequuntur. hiac ex causa licet non sint heredes instituti, domini sunt: nec obstat, quod licet cos exheredare, quod et occidere licebat". ("En los herederos suyos aparece con más evidencia, que la continuación del dominio lleva la cosa a la que no se considere que hubo herencia, como si en otro tiempo fueron dueños los que también en vida del padre son considerados en cierto modo como dueños; por lo cual se llama también hijo de familia, como padre de familia, habiéndose añadido solo esta diferencia, por la cual se distingue al engendrador del que fue engendrado. Asi, pues, no se considera que después de la muerte del padre reciben la herencia, sino más bien que consiguen la libre administración de los bienes; y por esta causa, aunque no hayan sido instituidos herederos son dueños, y no obsta que sea lícito desheredar, a los que también era lícito matar").

17 Gayo 3, 154 a: "Est autem aliud genus societis proprium ciuium Romanorum. Olim enim mortuo patre familias, inter suos heredes quaedam erat legitima simul et naturalis societas, quae appellabatur ercto non cito, id est dominio non diuiso: erctum enim dominium est, unde erus dominus dicitur; ciere autem diuidere est: unde caedere et secare et dividere dicimus". ("Pero también hay otra que es propia de los ciudadanos romanos, ya que antiguamente, al morir el padre de familia, quedaba formada entre los herederos un género de sociedad, a la vez legitima y natural, denominada ercto non cito, esto es, de propiedad indivisa, pues erctum es el dominio, de donde se deriva erus; el propietario, y cierre es dividir, de donde decimos caedere por cortar y dividir"). Gayo 3, 154b: "Alii quoque qui uolebant enadem habere societatem, poterant id consequi apud praetorem certa legis actione. In hac autem societate fratrum... ceterorumue, qui ad exemplum fratrum suorum societatem coierint, illud proprium erat, quod uel unus ex sociis communem seruum manummittendo liberum faciebat et omnibus libertum adquirebat: item unus rem communem mancipatio". " "Si otras personas querian formar esta clase de sociedad, podian conseguirlo ante el pretor mediante una determinada acción de la ley. Caracteristica especial de esta sociedad de hermanos o de personas que la constituian a imitación de los hermanos, era que si uno de los socios manumitía al esclavo común, lo hacía libre y liberto de todos los socios, y también que cuando uno mancipaba una cosa común, lo hacia de quien la recibia en la mancipación"). 
(Hausgemeinschaft). En vida del pater familia, dicho dominio era eventual, porque sólo éste conservaba la facultad de disposición, pero muerto el pater familia, como consecuencia de la consortio ercto non cito, los herederos se encontraban unidos por una sociedad de hecho, en la que no existía propiedad individual, sino una universalidad, con efectos muy diversos a la construcción posterior de la herencia y de la calidad de herederos. En primer lugar, porque, los "socios" o consortes quedados a la muerte del padre, no gozaban de cuotas; en segundo término, como se desprende de

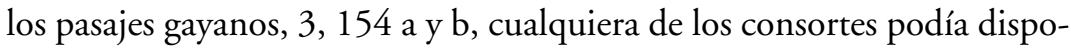
ner de los bienes, con pleno efecto respecto de los otros (recordemos, de paso, el efecto atributivo, no declarativo, de la adjudicación en Roma); en tercer lugar, la posibilidad de que terceros pudiesen voluntariamente constituir dicho consorcio (de ahí que se le considere el antecedente del contrato de sociedad)..$^{18}$

Kaser propone desde aquí su tesis de que la propiedad en la Roma arcaica tenía carácter relativo, porque su desarrollo vino de la mano del procedimiento romano y, en particular, de la actio sacramentum in rem. Como argumenta Kaser, según nos informa Gayo 4, 16-17, el procedimiento se caracterizaba especialmente por su simetría procesal, de modo que la declaración de dominio se realizaba en favor de quien lograba probar in iure la posesión, en otros términos, que no existía la preeminencia de una facultad protegida en favor de un sujeto, dirigida contra el poseedor de la cosa (una genuina reivindicatio), sino que la reivindicación se traducía en la declaración de que una persona tenía más (o mejor derecho) de poseer que otro. Y, por tanto, la diferenciación de roles en el procedimiento formulario, como veremos en breve, contribuirá a desarrollar la idea de dominio romano. ${ }^{19}$

Aunque esta tesis de Kaser es debatida (y en general se opone a los planteamientos de la doctrina italiana sobre los poderes del pater), nos parece un interesante punto de partida y proporciona poderosas razones para explicar la ausencia de un concepto de dominium. Consideramos que tanto la tesis de Bonfante (sobre los poderes del pater familias), como la de Kaser, hacen ver que el dominio romano arcaico tenía un carácter difuso, en buen medida por la inexistencia de otras potestades reales reconocidas sobre la cosa.

Dicho punto de partida permite situar, a nuestro juicio, dos etapas, que

${ }^{18}$ KaSER, Max, Derecho privado romano (trad. de la 5a edición alemana por José Santa Cruz Teijeiro, 2a edición, Madrid, Reus, 1982), pp. 101-102.

19 KASER, cit. (n. 18), pp. 101-102. 
aunque no puedan explicarse de modo estrictamente cronológico, si nos proporcionan luces sobre el origen y la evolución del dominio. Veamos.

En una primera etapa, muy primitiva, los bienes mancipi, así como la mancipatio, habrían comprendido simplemente los bienes muebles. En principio, la mancipatio, como informa Gayo 1, 121, habría supuesto la aprehensión material de la cosa. Así, los predios, según Gayo, son vendidos en ausencia: praedia uero absentia solent mancipari. ${ }^{20}$ En tanto, la primitiva vindicatio también habría supuesto la sujeción de la cosa, puesto que, Gayo 4, 17, nos dice que si la cosa no puede transportarse, se realiza la vindicación de una parte, como si se tratara del total. Ahora bien, desde aquí Capogrossi deduce que en una etapa inicial la propiedad individual debió haber estado limitada a los bienes muebles, libremente transferibles entre sujetos sui iuris; en cambio, los bienes raíces se encontraban, según el autor, en un situación intermedia: si bien es cierto el heredium y la casa construida se asignaron individualmente a cada pater familia, se sustrajo la disponibilidad de los bienes, que tenían, en consecuencia, un carácter común. Se aseguraba así, la propiedad familiar, asociada a la sucesión $a b$ intestato. El mismo término heredium revelaría que la primera forma de transmisión fue sólo a la muerte del padre. Aun así el autor indica que en todo caso, dicha imposibilidad de transferir inmuebles tuvo que haber operado en una etapa muy temprana, pues a la época de las XII Tablas, la propiedad raíz ya se habría incorporado a los bienes mancipi. ${ }^{21}$

20 Según el pasaje: "In eo solo praediorium mancipatio a ceterorum mancipatione differt, quod personae seruiles et liberae, item animalia, quae mancipi sunt, nisi in praesentia sint mancipari non possunt; adeo quidem ut eum, <qui> mancipatio accipit, adprehendere id ipsum, quod ei mancipatio datur, necesse sit: unde etiam mancipatio dicitur, quia manu res capitur, praedia uero absentia solent mancipari". ("En cuanto a los predios, la mancipación difiere de las otras cosas, esto es, de las personas, en que si no están presentes no pueden ser vendidas. Y es necesario que el comprador sostenga el objeto que se le ha vendido; de ahi deriva el nombre de mancipación, que se coge con la mano. En cambio, los predios suelen ser vendidos no estando presentes").

${ }^{21}$ Capogrossi, cit. (n. 11), pp. 170-171. En verdad esta idea ha sido planteada por otros autores, entre los que destaca Mommsen, Theodor, "Mancipium", "manceps", "praes", "praedium”, en ZSS, 23 (1902), pp. 438 y ss. También entiende el problema de modo similar, Fuenteseca DegenefFe, Margarita, La formación romana del concepto de propiedad (Madrid, Dykinson, 2004), p. 24. Como indica AmunÁtegui Perello, Carlos, Origen y función de la "Mancipatio", en REHJ, t. XXXIII (2011), p. 56, la titularidad individual de los inmuebles es atribuida por la leyenda a Rómulo, quien habría distribuido lotes individuales de dos yugadas a cada pater familias, llamados Heredia. El autor atribuye la labor de demarcación a los reyes etruscos, puesto que: "El heredium es una forma gromática, y sabemos que las reglas de división de la tierra y toda la agrimensura romana son de origen etrusco, según afirman varias fuentes independientes. Por lo demás, la medida misma, el heredium, es una unidad gromática 
Esta idea que parece desde luego brillante, no está exenta de críticas. En primer lugar, está la cuestión de las características de la economía rural en Roma, materia desde luego ajena a los propósitos de este trabajo, pero si se asume que la propiedad era, a la época del desarrollo de la mancipatio y, por tanto, de los bienes mancipi y nec mancipi, una sociedad agrícola, antes que pastoral, es difícil sostener el argumento de Capogrossi. Si, por el contrario, se considera que la sociedad primitiva tenía carácter pastoral, se llegará a la conclusión de que los bienes raíces no pudieron pertenecer a la categoría de los mancipi originariamente. ${ }^{22}$ Con buenos argumentos, Amunátegui ha puesto en duda la tesis de que los orígenes de la sociedad romana fuesen pastorales, sino por el contrario, afirma que: “...salvo que creamos que los romanos eran un pueblo excepcionalmente atrasado respecto de sus vecinos, debemos admitir que la aldea del Palatino estaba dedicada a

etrusca y no es otra cosa que la traducción latina de acnua, una medida ampliamente utilizada por las poblaciones etruscas para la división de la tierra, cuestión que ratifica el testimonio de Varrón". Antes, el autor había profundizado en esta cuestión en AMUNÁTEGUI Perello, Carlos, "Las gentes y la propiedad colectiva", en REHJ, t. XXXII, (2010), p. 42.

${ }^{22}$ Véase De Martino, Francesco, Historia económica de la Roma antigua (trad. de Ester Benítez, Madrid, Akal, 1985) t. I, pp. 10-12. Como dice el autor: "En la época de los orígenes, Roma fue una pequeña aldea habitada por pastores de origen indoeuropeo, que estaban descubriendo la agricultura. La actividad predominante, en efecto, era el pastoreo, y no la agricultura, como se deduce de la existencia de grandes bosques, cuyo nombre recordaba la toponimia, como Querquetual, Fagutal, Viminall, y como indica el hecho de que, en épocas más recientes, el Lacio e Italia fueran descritos por los naturalistas griegos como una tierra famosa por sus bosques de laureles, mirtos y espléndidas hayas. En la edad imperial hay testimonios sobre árboles gigantescos, quizá restos de bosques primigenios. También la religión conserva indudables elementos del carácter pastoral de la economía arcaica. El rito de los Lupercos, que pertenece a la originaria religión romana y aparece ligado a las gentes Fabia y Quinta, nos muestra una relación con las creencias, aún totémicas, en las cuales el caper hircus, el sacer hircus se ayuntaba con las mujeres o éstas resultaban fecundas uniéndose con el caprificus en el culto de Iuno caprotina. Las diversas etimologías o explicaciones de Fauno "semejante al lobo" o bien de lupi-hirci, es decir, lobos y carneros de lugares diversos, luego unidos, o bien de lupis arcendis o incluso de lupi-cervi, lobos que atacan a los ciervos, y otras muchas, tienen todas una innegable relación con lupus. Hay, pues, una prueba bastante segura de que el lobo era un animal sagrado, objeto de culto totémico, y esto, unido al hecho de que la cueva de Luperco estuviera considerada como el lugar sagrado más antiguo de Roma, nos confirma la idea de que la economía primitiva era de carácter pastoril. También otras divinidades arcaicas son pastoriles, como Pales y Forda, Caco y Caca, en cuya ara del Palatino ardía un fuego perpetuo. La propia leyenda sobre los orígenes de Roma, elaborada por historiadores griegos, como Timeo y Jerónimo de Cardia, que tuvieron un conocimiento directo de las noticias, tomándolas el primero, según los historiadores posteriores, de las poblaciones agrícolas de la región, parece entrelazarse con elementos de una sociedad pastoril". 
la agricultura, aunque el pastoreo tuviese una función económica importante, la cual, por lo demás, jamás desapareció". 23

Ahora bien, con una perspectiva distinta a la mayoritaria, es decir, considerando que la sociedad romana primitiva debió haber sido preeminentemente agrícola, Amunátegui también ha defendido la existencia de una misma ceremonia primitiva, tanto para bienes raíces, como para muebles. En su concepto, la creación de formas simbólicas, tanto para la mancipatio, como para la vindicatio en el caso de los inmuebles, revelaría la misma forma mentis de realizar la ceremonia. Pero, desde ahí, el autor argumenta además que los bienes mancipi comprendieron originariamente los bienes raíces y aquellos bienes destinados a la explotación agrícola de carácter gentilicio (lo que explicaría, por un lado, la exclusión de bienes de explotación, como el arado; $y$, por otro, la adhesión del autor a la tesis de Bonfante sobre la titularidad gentilicia de la tierra). Precisamente, siempre según Amunátegui, la pertenencia de los bienes a las gentes, demostraría la necesidad de una ceremonia destinada a dar certidumbre de los intercambios que fundamentarían la riqueza de los bienes de mayor importancia en la primitiva Roma. Por el contrario, considera que bienes como los esclavos, fueron incluidos entre los bienes mancipi con posterioridad. ${ }^{24}$

Un segundo aspecto de aquello que hemos denominado etapa, vendría determinada por la diferencia entre los bienes mancipi y nec mancipi en relación con el dominium. Bonfante, que radica la titularidad de los bienes mancipi en la gens, como depositaria de los bienes pretiosores (según Gayo 1, 192), es decir, los de mayor valor económico en la sociedad romana, propuso la idea de que mientras los bienes mancipi desarrollaron el concepto del dominium o la plena titularidad sobre una cosa (el dueño lo es meum esse ex iure Quiritum), los bienes nec mancipi permitieron el desarrollo de la idea de posesión, puesto que la traditio, primitivamente, habría supuesto sólo el traspaso de la posesión material (meum esse). ${ }^{25}$ Es claro que esta tesis resulta del todo opuesta al planteamiento de Kaser, como hemos advertido. Sin embargo, Capogrossi anota la importante cuestión de que tiene que haber sido una diferencia superada muy pronto, por cuanto la actio sacramentum in rem no estuvo limitada sólo a los bienes mancipi (y

23 Amunátegui, cit. (n. 21) pp. 43-45 y Amunátegui, cit. (n. 21) pp. 42-46. D'Ors, cit. (n. 6), p. 182 también sostiene que los bienes mancipi correspondía a los de mayor importancia en una economía agraria. Véase también, en el mismo sentido, García Garrido, cit. (n. 6), p. 144.

${ }_{24}$ Véase Amunátegui, cit. (n. 21), pp. 54-58; y, Amunátegui, cit. (n. 21), pp. 51-56.

${ }^{25}$ Bonfante, cit. (n. 11), pp. 253 y ss. 
cuyo reflejo se encuentra en la in iure cessio, que se aplicaba para ambos tipos de bienes). ${ }^{26}$

No podemos continuar extendiéndonos en demasía en esta cuestión, pero deben anotarse, para comprender la evolución romana de modo más acabado, algunos aspectos. De un lado, hacia siglo III a.C., Roma había venido sufriendo cambios de importancia económica y social: había dejado de ser una pequeña ciudad para ir ocupando lentamente el lugar de preeminencia en el mediterráneo (comprendiendo en ello las guerras púnicas). Este cambio profundo, paulatino, pero progresivo, trae dos consecuencias de importancia en la materia que estudiamos. En primer lugar, el reconocimiento de una titularidad absoluta sobre todas las cosas, incluidos los esclavos; en segundo término, la distinción del dominio de otras formas de relaciones reales, como el usufructo y la servidumbre. ${ }^{27}$ Un impulso de tales cambios fue sin duda alguna la introducción del procedimiento formulario, que modificará profundamente el sistema de acciones. ${ }^{28}$ Aun así, la expresión dominium para reflejar este tipo de relaciones, aparecerá recién en la época tardo-republicana. ${ }^{29}$

En esta línea, es destacable el pasaje de Ulpiano recogido en D. 9, 2, 11, 6, a propósito de la lex Aquilia, que expresa: "Legis autem Aquiliae actio ero competit, hoc est dominio" ${ }^{30}$ Capogrossi argumenta que el pasaje revela

${ }^{26}$ Capogrossi, cit. (n. 11), pp. 172-173.

${ }^{27}$ Hay acuerdo en la romanística en el sentido de que gracias a la configuración de la servidumbre y el usufructo (cosas incorporales para Gayo), el dominio terminó siendo entendido como el poder más amplio sobre las cosas. Frente a potestades parciales sobre la cosa, el concepto relativo de dominio se erige como el conjunto de potestades más amplias. Véase, en este sentido, TalamancA, Mario, Istituzioni di Diritto Romano (Milano, Giuffrè, 1990), p. 391; Cannata, Carlo Augusto, Corso di Istituzioni di Diritto Romano (Torino, Giappichelli, 2001), p. 161; Miceli, cit. (n. 13), p. 253.

${ }^{28}$ Véase, sobre esta cuestión, el ya citado Capogrossi, cit. (n. 11) pp. 177-178.

${ }^{29}$ GuZMÁn Brito, cit. (n. 6), pp. 497-502. García Garrido, cit. (n. 6), p. 149, agregando que no parece conocer el término Cicerón, pero si Alfeno Varo, cónsul el año 30 a.C.

30 Para ARnò, Carlo, Legis Aquiliae actio directa ero competit, en BIDR 42, (1934), p. 197, este pasaje no es más que una consecuencia de la forma en la que se otorgaba la acción en los capítulos primero y tercero de la ley, dado que se utilizaba la categórica expresión domino dare damnas esto. De otro lado, Ferrini, Contardo, La legitimazione attiva nel' "actio legis Aquiliae". Opere di Contardo Ferrini (Milano, Ulrico Hoepli, 1930), t. V, p. 193, indica que la acción se otorgaba al propietario al momento de cometido el menoscabo, con independencia que posteriormente lo perdiera pues, dado que en su concepto se trataba de una acción originariamente penal, su función era reparar el atentado al derecho del propietario y no resarcir el menoscabo. 
la unificación, en el concepto, de las distintas potestades sobre cosas y la deshumanización que reflejaba considerar el esclavo una cosa, toda vez que el término erus representaba el señorío sobre esclavos, pasando a ser reemplazado por la expresión dominium. ${ }^{31}$

\section{EL CONCEPTO DE DOMINIO EN ÉPOCA CLÁSICA Y}

\section{POSCLÁSICA}

Podríamos comenzar señalando que en etapa clásica, llegaron a distinguirse distintas clases de dominio. En primer lugar, el dominio quiritario (ex iure quiritum), que supone como titular un ciudadano romano que hubiera adquirido la cosa mediante un modo reconocido por el ius civile (mancipatio o in iure cessio). Si era un fundo, debía estar situado en suelo itálico. Sólo en este caso, se concedía en favor del propietario una acción reivindicatoria. Frente a este concepto encontramos el dominio bonitario (tener entre los bienes una cosa o in bonis habere). ${ }^{32}$ La propiedad bonitaria amparaba la

31 Capogrossi, cit. (n. 11), p. 178. Como puntualiza Valditara, Giuseppe, Damnum iniuria datum, en PARICIO Serrano, Francisco Javier (coordinador), Derecho Romano de Obligaciones. Homenaje al profesor José Luis Murga Gener (Madrid, Centro de Estudios Ramón Areces, 1994), p. 873: "Più specificamente sappiamo da Ulpiano che il capo della legge parlava originariamente di erus come di colui al quale era riservata la legittimazione ad agire. In conformità con il significato più antico del termine, ancora evidente nelle commedie plautine, con erus se alludeva in paticolare al padrone di servi e verosimilmente di quadrupedi. Erus, cioè, indicava una figura specifica di proprietario". Agrega: "Per quanto riguarda il capo terzo si è pensato da più parti che anche con riferimento al esso la legge usasse il termine erus. Si può tuttavia osservare como il chiarimento che legis Aquiliae actio ero competit è fatto da Ulpiano in occasione del solo commento al capo primo, mentre a propósito del capo terzo il giurista riporta dominus nel terzo senza agguingere alcun chiarimento ulteriore. Questa considerazione, unità alla constatazione del significato ristretto di erus, non consente di presumere che detto termine fosse impiegato anche con riferimento al capo terzo".

32 GuZmán Brito, cit. (n. 6), p. 503. Como explica Guarino, Antonio, Istituzioni di Diritto Romano (Napoli, Editorie Jovene, 2006), pp. 124-126, la posesión era una relación basada en la disposición actual y efectiva de la cosa, reconocida por la costumbre social romana, desde los tiempos más antiguos, pero que operaba fuera de la órbita del Derecho quiritario y, por consiguiente, recaía sobre bienes nec mancipi. Posteriormente, esa situación fáctica sobre la cosa fue reconocida por el Derecho quiritario, denominado usus, estructuralmente análogo a la posesion extrajurídica, cuando un padre o jefe de familia detentaba cosas ajenas. los interdictos nacen para la protección de los denominados poseedores naturales o pretorios que son, en estricto rigor, meros detentadores. Así la acción se otorgó originalmente a favor del vectigalista o tenedor de una parcela del ager publicus, del precarista o el que ha recibido un inmueble del dueño por concesión graciosa; el secuestrario, es decir, la persona a quien se entrega la cosa que se disputa en un juicio reivindicatorio. Sin perjuicio 
posesión, mediante la acción publiciana, creada por el pretor. Los casos de propiedad bonitaria, fueron los siguientes: a) si el propietario de una res mancipi la enajenaba mediante una traditio (no a través de la mancipatio o la in iure cessio); ${ }^{33}$ b) si alguien, que no era dueño transfertransfer ontrar diía una cosa (mancipi o nec mancipi). El verdadero dueño contaba con la reivindicatio, en tanto no operara la usucapio en favor del poseedor, pero éste gozaba de la actio publiciana para proteger su posesión (fórmula que consagra actualmente el artículo 899 del Código civil) ${ }^{34}$ Hubo otros casos de dominio pretorio, pero no vamos a detenernos en ellos, en razón del objeto del presente trabajo. También debemos tener presente que hubo otros casos de propiedad, como aquella otorgada a los peregrinos, incluso sobre fundos itálicos, cuando reclamaban cosas que le pertenecían (Gayo 4,37 , se refiere a las acciones ficticias a favor de los peregrinos -se finge el carácter de ciudadano-, aunque no menciona expresamente la reclamación de cosas). D'Ors la denomina, precisamente, propiedad peregrina e incluso, en un período más tardío, de una propiedad "provincial” para los fundos provinciales, pertenecientes al Príncipe o al erario (según si la provincia era senatorial o administrada por el Príncipe). ${ }^{35}$

El principio en esta materia, aparece en Gayo 2,40: "Sequitur ut admoneamus apud peregrinos quidem unum esse dominium: nam aut dominus quisque eta ut dominus non intellegitur. Quo iure etiam populus Romanus olim utebatur: aut enim ex iure Quiritium unuquisque dominus erat aut non intellegebatur dominus. Sed postea diuisionem accepit dominium, ut alius possit esse ex iure Quiritium dominus, alius in bonis habere". ("Procede considerar el

de lo anterior, el interdicto fue extendido naturalmente también al poseedor civil, denominado usus, es decir, a quien detenta la cosa como señor y dueño, aunque no lo fuera.

${ }^{33}$ Gayo se refiere específicamente a este caso en 2, 41: "Nam si tibi rem mancipi neque mancipauero neque in iure cessero, sed tantum tradidero, in bonis quidem tuis ea res effcietur, ex iure Quiritium vero mea permanebit, donec tu eam possidendo usucapias: semel enim impleta usucapione proinde pleno iure incipit, id est et in bonis et ex iure Quiritium tus res esse, ac si ea mancipata uel in iure cessa <esset". ("Efectivamente, si yo te diera una cosa mancipable y no te mancipara no cediera ante magistrado, sino únicamente entregara, dicha cosa se hace tuya por derecho pretorio, pero sigue siendo mía por derecho civil, hasta que tú consigas usucapirla con la posesión; una vez realizada la usucapión, empieza a ser tuya de pleno derecho, esto es, no sólo por derecho pretorio, sino además en propiedad civil, exactamente igual que si te hubiera sido mancipada o cedida ante magistrado").

${ }^{34}$ Trata Gayo 2, 45, 49 y 50, la posibilidad de usucapir las cosas ajenas adquiridas de buena fe, con la limitación de las cosas hurtadas o robadas. Para la posibilidad de usucapir el esclavo adquirido de buena fe, véase Gayo 2, 93. Sobre estas clases de propiedad clásica, CAPOGROSSI, cit. (n. 11), pp. 200-202.

35 D'Ors, cit. (n. 6), p. 190. 
único tipo de dominio que existe entre los peregrinos, pues según ellos, alguien o es dueño o no es dueño. Este era también, antiguamente, el derecho del pueblo romano, y cada persona era dueña según el derecho los Quirities, o bien no se consideraba dueña. Pero después, el dominio experimentó una división, para que pudiera uno ser dueño según el derecho de los Quirities, o según el derecho pretorio"). Siguiendo a Kaser, es probable que el pasaje gayano nos indique que la acción publiciana se otorgó primitivamente para proteger la adquisición de bienes mancipi que no habían respetado la solemnidad de la mancipatio, extendiéndose posteriormente a la enajenación de cosa ajena, cuando las necesidades del comercio así lo dictaron. ${ }^{36}$

Lo que resulta claro es que la clasificación de los bienes mancipi y nec mancipi, así como la ceremonia de la mancipatio, fue perdiendo paulatina importancia en una sociedad que fue desarrollándose hasta alcanzar los estándares de un imperio mediterráneo. Como indica Alföldy, en sólo 100 años Roma pasó a ser el dueño de un vasto territorio, que le permitió abastecer con largueza las necesidades de su población. Dice el autor: " $E l$ joven imperio englobaba inmensos territorios con una capacidad de producción agraria altamente desarrollada, que posibilitaban la importación de articulos de primera necesidad a Italia y que aqui, por ejemplo, hacian en gran medida superfluo el cultivo de cereales; poseía recursos casi inagotables de materias primas, que, como las minas de plata en Hispania, eran explotadas en su directo beneficio; disponia ahora de cantidades ilimitadas de fuerza de trabajo más barata, concretamente, esos millones de prisioneros de guerra esclavizados y de provinciales carentes de derechos; tenía para sus productos manufacturados un extenso número de mercados, libres de toda concurrencia; en fin, ofrecia a los particulares y a los grupos inmensas posibilidades para la inversión, la actividad empresarial y la economía monetaria. Todos estos nuevos factores en el desarrollo económico conducían necesariamente también a una transformación de la sociedad". ${ }^{37}$

Siendo este el escenario, no puede sorprendernos que la traditio fuera en definitiva a venir en reemplazo de la mancipatio, porque su sencilla forma respondía bien a las necesidades del comercio y se adaptó a los efectos que venían configurándose con las distintas formas de propiedad creadas en el contexto del procedimiento formulario.

36 Véase Kaser, cit. (n. 18), p. 438 y CAPOgrossi, cit. (n. 11), p. 198.

37 Alföldy, Géza, Historia social de Roma (trad. de Víctor Alonso Troncoso, $3^{\text {a }}$ reimpresión $1^{\text {a }}$ edición, Madrid, Alianza Universidad, 1996), pp. 37-38; 47-49. Algunos hechos, como un nuevo orden social, representado por el orden equestre (hombres acaudalados, interesados en el comercio fundamentalmente) y un aumento considerable en la mano de obra barata, a través del comercio de esclavos, contribuyó al cambio de fisonomía de la sociedad romana. 
En efecto, el desarrollo del concepto de dominium se produce especialmente en el ámbito del procedimiento formulario, como se ha venido afirmando. ${ }^{38}$ En dicho contexto, por ejemplo, se explica la cuestión de la ampliación de la legitimación de la lex Aquilia, lo que supuso, como en el pasaje de Ulpiano que hemos citado, la construcción de un concepto de dominio a partir del cual pudiera extenderse la protección de la ley mediante acciones útiles. ${ }^{39}$ Abolido el procedimiento de acciones de la ley, ${ }^{40}$ como indica Fuenteseca, en época clásica, la división fundamental de las acciones se había limitado a las figuras de la actio in rem y de la actio in personam. Agrega: "Ambas formulaciones proceden históricamente de las legis actiones y se insertaron en las formulae del procedimiento formulario. Nos hallamos ante un testimonio claro de la doble linea evolutiva de la historia del proceso romano: una que conduce desde la legis actio sacramento in rem (=vindicationes) hasta la actio in rem del proceso formulario, y otra que parte desde las dos legis actiones per iudicis postulationem y per condictionem y conduce hasta la actio in personam clásica, en cuya fórmula se exige un débito pecuniario..." ".1 Parece evidente que, a la época de vigencia del procedimiento formulario de modo pleno, la formación de la actio in rem, por contraposición a la actio in personam, importó que tanto el concepto de dominio, como de la posesión (porque contra poseedor se dirige la acción reinvidicatoria), ya estaban formados. Por ello, en el pasaje del Digesto $44,7,25$, puede afirmarse que: "In rem actio est, per quam rem nostram, quae ab alio possidetur, petimus; et Semper adversus eum est, qui rem possidet". ("Acción real es aquella por la cual pedimos una cosa nuestra, que es poseida por otro; y es siempre contra el que posee la cosa").

La evolución del dominio en la época posclásica va, por un lado, a consolidar el dominio frente a estas diversas formas que hemos visto, es decir, en la medida que pierde fuerza y sentido la mancipatio; por otra

38 En este sentido, Miceli, cit. (n. 13), 255.

39 Sobre esta cuestión, véase nuestro trabajo AEdo BARRENA, Cristián, La ampliación de la legitimación activa en la lex Aquilia, en Revista General de Derecho Romano, 17, (2011), pp. 1-19.

${ }^{40} \mathrm{Si}$ bien es cierto las acciones de la ley fueron sustituidas por las acciones formularias, lo que no está claro y es sumamente discutido por la doctrina es la forma en la que se produjeron dichas aboliciones y a cuáles leyes, exactamente, se refiere Gayo en su pasaje. Sobre el tema, véase LEVY-BRUHL, H., Recherches sur les actions de la loi (Paris, Sirey, 1960), pp. 324 y ss.

${ }^{41}$ FuenteseCA, Pablo, La obligatio como vinculum iuris (civilis) y la obligatio rei pignoris causa, en AA.VV., Iuris Vincula. Studi in onore di Mario Talamanca (Napoli, Jovene Editore, 2011), t. III, pp. 467-468. En efecto, Gayo dedica el cuarto comentario a las acciones y comienza indicando que éstas se dividen en dos: la actio in rem y la actio in personam. 
parte, contribuye que el ius civile deje de estar completamente separado del derecho honorario. Paulatinamente, pues, las diversas formas de dominium van a adoptar una forma unitaria. Por ejemplo, cobra cada vez más fuerza la distinción entre los bienes muebles-inmuebles (antes que la tradicional dicotomía mancipi-nec mancipi), ${ }^{42}$ al punto que Capogrossi señala que en la etapa postclásica, las diferencias entre posesión y dominio tienden a desaparecer. ${ }^{43}$ Ello es muy claro en lo que veremos seguidamente como posesión civil (o, como la hemos denominado, propiedad bonitaria).

Como indica Cannata, la reforma del sistema fue realizada mediante dos constituciones imperiales, ambas de Justiniano, recopiladas en el Codice. La C. 7,25,1, del año 530 (aunque de fecha imprecisa), ${ }^{44}$ eliminó la distinción entre dominium ex iure Quiritium y propiedad in bonis habere. La segunda constitución, también de Justiniano, recopilada en C. 7, 31,1, ${ }^{45}$

${ }^{42}$ En este sentido, SAmPER, Francisco, Derecho romano (Santiago, Ediciones Universidad Internacional Sek, 1993), pp. 112-113.

${ }^{43}$ Capogrossi, cit. (n. 11), pp. 217-219.

${ }^{44}$ La constitución reza: "Antiquae subtilitatis Iudibrium per hanc decisionem expelentes, nullam esse differentiam patimur inter dominos, apud quos vel nudum ex "iure Quiritium", vel tantummodo in bonis repeteritur, quia nec huiusmodi volumus esse distinctionem, nec "ex iure Quiritium" nomen, quod nibil ab aenigmate discrepat, nec unquam videtur, nec in rebus apparet, sed vacuum est et superfluum verbum, per quod animi iuvendum, qui ad primam legum veniunt audientiam, perterriti ex primis eorum cunabilis inútiles legis antiquae dispositiones accipiunt. Sed sit plenissimus et legitimus quisque dominus sive servi aliarum ad se pertinentium" ("Repeliendo por esta decisión el ludibrio de una antigua sutileza, no consentimos que haya diferencia alguna entre los dueños, en quienes una cosa se halla o nuda "por derecho de Quirities", o solamente en sus bienes, porque no queremos que exista semejante distinción, ni la frase "por derecho de los Quirities", que en nada se diferencia de un enigma, ni nunca se ve ni aparece en las cosas, sino que es frase vacía y superflua, y perturbada por ella la inteligencia de los jóvenes, que asisten a las primeras lecciones de leyes, aprende en sus primeros comienzos inútiles disposiciones de la ley antigua. Más sea cada cual plenisimo y legítimo dueño, ya del esclavo, ya de los demás bienes que a él le pertenezcan").

${ }^{45}$ Se trata de un larguísimo texto, del que recogeremos tan sólo algunas partes: C. 7, 31, 1pr.: "Quum nostri animi vigilantia "ex iure Quiritium" nomen et substantiam sustulerit, et comunes exceptiones in omni loco valeant decem vel viginti vel triginta annorum, vel si quae sunt aliae maioris aevi continentes prolixitatem, satis inutile est, usucapionem in Italicis quidem soli rebus admittere, in provincialibus autem recludere. Sed et si quis res alienas, Italicas tamen, bona fide possidebat per biennium, miseri rerum domini excludebantur, et nullus eis ad eas reservabatur regressus. Quae et nescientibus dominis precedebant; quo nihil inhumanius erat, si homo absens et nesciens tam angusto tempore suis cadebat possessionibus". ("habiendo suprimido la previsión de nuestra inteligencia el nombre y la esencia de "derecho de los Quirites", y siendo válidas en todo lugar las excepciones comunes de diez, o de veinte, o de treinta años, o las que haya que contengan la prolijidad de mayor tiempo, es bastante inútil admitir la usucapión cierta- 
de 15 de noviembre del año 530, reorganizó el sistema de prescripción de los bienes, suprimiendo la distinción entre biene mancipi y nec mancipi, estableciéndose la traditio como el modo universal de adquirir la propiedad por acto entre vivos. ${ }^{46}$

Hasta aquí puede seguirse la evolución del dominio, en lo que a nuestra investigación respecta. Veamos ahora de qué modo pueden ser analizadas las relaciones entre el concepto de dominio en Roma y la definición contenida en nuestro Código civil.

\section{IV. ¿EXIstió EN El Derecho ROMANO Un DEREChO SUBJETIVO EN EL CASO DEL DOMINIUM?}

Como apunte metodológico, siguiendo a Guzmán Brito, la cuestión no consiste en decidir si los juristas romanos reconocieron los poderes o facultades de un sujeto. Lo decisivo, en su concepto, es que se hayan designado dichas facultades o poderes como derecho. Desde esta perspectiva, Guzmán Brito advierte que las fuentes tienen múltiples referencias a potestas o facultades, pero, añade, en ninguna de ellas se las califica como ius. ${ }^{47}$ En un sentido similar, Gioffredi ${ }^{48}$ ha argumentado que la expresión ius, en el sentido subjetivo con el que se le empleaba en el Derecho romano, podía significar: a) esfera jurídica, condición o posición jurídica; b) prerrogativa, atribución, facultad, título. Con todo, el autor, entiende que falta todavía

mente respecto de los bienes raices de Italia, y denegarla en cuanto a los de las provincias. Más también si alguno poseía de buena fe por dos años bienes ajenos, pero de Italia, eran excluidos los miseros dueños de los bienes, y no se les reservaba ningún regreso a ellos. Lo cual era procedente aún ignorándolo los dueños; y nada era tan inhumano como que un hombre ausente y que lo ignoraba decayera en sus posesiones en tan corto tiempo"). C. 7, 31, 1, 4: "Ita etenim ampliatur quidem longi temporis materia, quae ei súbdita est, minuitur autem usucapionum compendiosa dominis iactura et eius iura nocentia, quum etiam res dividi mancipi et nec mancipi sane aintiquum est, et merito antiquari oportet, utsit rebus et locis ómnibus similis ordo, inutilibus ambiguitatibus et differentiis sublatis" ("Así, pues, se amplia ciertamente la materia que a la de largo tiempo le está afecta, y se disminuye para los dueños la rápida pérdida de las usucapiones, y sus perjudiciales leyes, porque verdaderamente también es anticuado que las cosas se dividan en mancipi y nec mancipi, y con razón debe abolirse, a fin de que para todas las cosas y lugares haya análoga disposición, quedando suprimidas las inútiles ambigüedades y diferencias').

${ }^{46}$ Cannata, cit. (n. 27), pp. 168-169.

47 GuZmán Brito, Alejandro, Historia de la denominación del derecho-facultad como subjetivo, REHJ, t. XXV, (2003), p. 407.

${ }^{48}$ Gioffredi, Carlo, Osservazioni sul problema del diritto soggettivo nel Diritto romano, en $B I D R \mathrm{~N}^{\circ} 70$, (1967), pp. 231-235. 
en el Derecho romano un concepto autónomo y unitario, como complejo de facultades derivadas de una norma. ${ }^{49}$

En verdad, como advierte D'Ors, la expresión ius tiene un sentido único, intermedio entre norma y facultad: "que es precisamente, el de "posición justa"". Agrega el autor: "Como es sabido, el empleo del ius est resulta de un empleo antiquisimo, en paralelismo al fas est, sin que tengamos que entrar ahora en la cuestión de la distinción entre ius y fas, que nos alargaría excesivamente este articulo. Ahora bien: ius est no quiere decir, evidentemente, $n i$ «hay facultad" ni "hay norma», sino más bien "es justo» o «es una posición justa»". No obstante, como advierte, la distinción entre titularidad y normatividad, impropia de la mentalidad romana, se hizo posible gracias al monopolio por el emperador. El ius deja de ser una disposición privada y posibilita la aparición del Derecho objetivo, surgiendo en época postclásica la idea de ius como derecho subjetivo. ${ }^{50}$

${ }^{49}$ En el Digesto, al abordarse el significado de ius, no se lo identifica con el denominado derecho subjetivo. En efecto, en D. 1, 2, 11 pr., Paulo dice: "Ius pluribus modis dicitur. Uno modo, quum id, quod semper aequum ac bonum est, ius dicitur, ut est ius naturalle; altero modo, quod omnibus aut pluribus in quaque civitate utile est, ut est ius civile; nec minus ius recte apellatur in civitate nostra ius honorarium. Praetor quoque ius reddere dicitur, etiam quum inique decernit, relatione scilicet facta non ad id, quod ita Praetor fecit, sed ad illud, quod Praetorem facere convenit. Alia significatione ius dicitur locus, in quo ius redditur, apellatioen collata ab eo, quod fit, in eo, ubi fit; quem locum determinare hoc modo possumus: ubicumque Praetor salva maiestate imperii sui salvoque more maiorum ius dicere constituit, is locus recte ius apellatur". En cualquier caso, léase el pasaje con la prevención de VILLEY, Michael (1976): "Los orígenes de la noción de derecho subjetivo", en: El MISMO, Estudios en torno a la noción de derecho subjetivo, trad. de Alejandro Guzmán Brito (Valparaíso, Ediciones Universitarias de Valparaíso), p. 33, quien entiende que las nociones del ius recopiladas en el Digesto, como la de Paulo, que comentamos, trasuntan la filosofía griega, correspondiendo sus definiciones más a la palabra griega dikaion que a la concepción de ius. En cualquier caso, está de acuerdo que en este tratamiento de las primeras partes del Digesto, la palabra ius no significa nunca derecho subjetivo: “...Pues el Digesto, relativamente parco en este punto, se limita a sugerir la significación esencial de la palabra ius (lo justo, el objeto de la Justicia, aquello que encuentra su fuente en la naturaleza, las leyes civiles, el edicto del pretor o los tribunales), $y$, después, un pequeño número de sentidos derivados (el Arte de los justo, el lugar en donde se pronuncia lo justo, accesoriamente, el vínculo de parentesco)".

${ }^{50}$ D'Ors, Álvaro, Aspectos objetivos y subjetivos del concepto de ius, en AA.VV. Studi in memoria di Emilio Albertario (Milano, Giuffrè, 1953), pp. 295-297. Profundiza estos argumentos en D'Ors, Álvaro, Ius en sentido objetivo-subjetivo, AHDE, XXIV, (1954), pp. 635-640. Una opinión similar sostiene Cesarini SForza, Widar, Diritto soggetivo, en Enciclopedia del Diritto (Milano, Giuffrè, 1968), t. XII, pp. 663-665. El ius romano no podía identificarse enteramente con el conjunto normativo (dada la profusa fuente normativa romana), ni con la subjetividad del poder de un sujeto 
Villey, por su parte, ha hecho notar, entre los textos de Gayo, que la expresión ius no se refería únicamente a la facultad o potestad. Pone, como ejemplo, los pasajes gayanos 2, 12 y ss., en el que se enumeran diversas especies de iura: ius eundi, o derecho de pasar; stillicidium avertendi (de desviar las aguas lluvias), entre otros. Pero agrega Villey que también ius refiere situaciones negativas: ius non altius tollendi (derecho de no sobreelevar), stillicidium non avertendi (derecho de no desviar aguas lluvias); en suma, que la expresión ius -traducido como derecho por comodidad-, refiere también a cargas. Ahora bien, en el plano sustantivo, Villey entiende que la jurisprudencia romana, fuertemente influida por la filosofía griega, no articulaba el estudio de las materias en función de los derechos de las personas. La jurisprudencia, por el contrario, tenía por objeto el estudio de las cosas y la condición de cada cosa en un mundo ordenado, es decir, el estatuto o condición de cada cosa. ${ }^{51}$

Robleda, por el contrario, ha sostenido que la idea de derecho subjetivo puede encontrarse en Gayo. Varios pasajes de las Instituciones le permiten pensar así, referidos a las relaciones de familia $(1,54$ y 55, relativos a la potestas del esclavo y del hijo, respectivamente). Para Robleda, en estos casos, que la potestad arranque del Derecho consuetudinario no implicó que ella no tuviera la sustancia o realidad de un verdadero derecho subjetivo. Dicha potestad se fundaría en la división de las personas, señalada en Gayo 1, 48-49. En el ámbito de los bienes, cita el pasaje de Gayo 2, 30, el que se refiere a la constitución del usufructo. En él, para Robleda, al hablarse de un retinere, efficere, habere, Gayo manifiesta la idea del ius como derecho y no como posición, pues: “...lo que viene retenido, creado (effectum), cedido, es aquello que se llama usufructo, nuda proprietas, ius, que

frente a otro. Cesarini la denomina, la unidad dinámica de la subjetividad y la objetividad, caracterizada por la famosa definición de la justicia. El ius es así el poder de un sujeto y la tipicidad de la situación práctica determinada.

${ }^{51}$ VILLEY, Michael, Las instituciones de Gayo y la idea de derecho subjetivo, en EL MISMO, Estudios en torno a la noción de derecho subjetivo, trad. de Francisco Bartolucci (Valparaíso, Ediciones Universitarias de Valparaíso, 1976), pp. 36; 42. En el mismo sentido, por ejemplo, TALAmanca, cit. (n. 27), pp. 386-387, quien indica que, no siendo desarrollada la idea de derecho subjetivo, las diferencias obligación-dominio se afrontaban desde la diferencias entre actio in personam-actio in rem. Véase también Capogrossi, cit. (n. 11), pp. 186-187; Miceli, cit. (n. 13), p. 257. En el derecho chileno, sólo hemos encontrado un autor que se ha preocupado del problema. Nos referimos al trabajo de LinazASORO CAMPOS, Gonzalo, Propiedad y cosas incorporales, derechos protegidos constitucionalmente a través de este derecho real, en VARAS BRAUN, Juan Andrés-Turner Saelzer, Susan (coordinadores), Estudios de Derecho Civil (Santiago, LexisNexis, 2005), 243. 
uno tiene o del que uno dispone". ${ }^{52} \mathrm{Y}$, para Cannata, el dominio se perfiló en el Derecho romano como un derecho subjetivo (concretamente, como una relación jurídica real, en la que el sujeto pasivo queda determinado con la violación del derecho). Aun cuando reconoce que los juristas romanos no emplearon la expresión derecho subjetivo, el concepto proviene del desarrollo dogmático en Roma y agrega que, sin embargo, los juristas romanos denominaron iura (ius en singular) los derechos reales sobre la cosa de otros. ${ }^{53}$

Sobre la discusión, que excede las pretensiones de nuestro trabajo, pueden extraerse reflexiones importantes para determinar el concepto clásico de dominium. En particular, respecto del tratamiento gayano, Villey expresa la acertada opinión de que la palabra iura, en la partición gayana de cosas, equivalía a cosas incorporales. En efecto, habrá que recordar que, entre las cosas, Gayo distingue las privatas y las publicae, y, dentro de las primeras, las corporales e incorporales (servitutes, ususfructus, hereditas, obligatio). Para Villey, Gayo recoge una tradición jurídica que deja sentir su influencia de la filosofía griega. Frente a las cosas corporales (corpóreas, materiales), el jurista ubica aquellas que son creadas por el Derecho y que existen, podríamos decir, idealmente. ${ }^{54}$ Por ello, en Gayo, obligatio y ius

52 Robleda, Olis, El derecho subjetivo en Gayo, en AA.VV. Studi in onore di Gaetano Scherillo (Milano, Istituto Editoriale Cisalpino-La Giolardica, 1972), t. I, pp. 9-13. Algunos autores, con una lectura procesal, hablan francamente de derechos subjetivos, a la hora de explicar la distinción clásica, propia del procedimiento formulario, entre actio in rem y actio in personam. Véase, por ejemplo, FUENTESECA, cit. (n. 41), p. 469: “... actiones in rem actiones in personam, en cuanto ambas actiones se convirtieron en instrumentos procesales, respectivamente, de los derechos reales (iura in re) $y$ de los derechos de obligación (ius obligationes in personam)".

53 Cannata, cit. (n. 27), pp. 153-154; 158.

${ }_{54}$ Más bien, se trata de la influencia del pensamiento estoico, concretamente, Cicerón. Véase, Arangio-Ruiz, Vicenzo, Istituzioni di Diritto Romano (reimpresión $14^{a}$ edición, Napoli, Casa Editrice Dott. Eugenio Jovene, 2012), p. 163. Como señala GUZMÁn BRITO, Alejandro, Las cosas incorporales en la doctrina y en el derecho positivo (2a edición actualizada, Santiago, Editorial Jurídica de Chile, 2006), pp. 19-38, la distinción entre los corpóreo e incorpóreo parece común a toda la filosofía griega. En ella, los filósofos distinguieron dos tipos de capacidades del alma humana: la de sentir, por la que se percibe lo corpóreo, y la de entender, que capta lo incorpóreo. Lo corpóreo es aquello que se puede percibir por los sentidos o que pueden ser tocados (comprendiendo la acción de todos los sentidos). No obstante, en cuanto a su naturaleza se aprecia una diferencia. Para la filosofía griega en general, tanto las cosas corpóreas, como incorporales, pertenecen al mundo del ser. Contrariamente a la filosofía clásica, afirma Guzmán Brito, el pensamiento estoico considera como género el "algo", que comprende tanto el ser, como el no ser. Ahora bien, el no-ser es identificado con lo incorpóreo. Entre los pensadores romano, Cicerón, en su obra 
obligationis, según Villey, significan lo mismo. El ius obligationis, al que expresamente hace referencia Gayo D. 1, 8, 1, 2, no representaba el derecho de crédito. ${ }^{55}$ No obstante, como ha hecho notar d'Ors, la afirmación de que el dominio no constituye un ius como en cambio, las servidumbres prediales y el usufructo, no impide que se establezca la conexión con el ius dominii, aunque, respetuoso de su pensamiento, d'Ors afirma que, especialmente en el pasaje D. 39, 2, 15, 33, referido al missus in posesionem, ius dominio significa la posición justa del dueño, no, por tanto, en el sentido de subjetivo. ${ }^{56}$

No tenemos razones para pensar que el dominio fuese considerado un derecho subjetivo. La potestad asociada al dominio no fue considerada como cosa incorporal. ¿qué es una cosa corporal, por tanto? Como indica Villey, la cosa corporal es, en principio, una cosa material, pero no solo el simple objeto material, sino una cosa cum iure suo, es decir, una cosa destinada a cubrir las necesidades del hombre, una cosa con un fin determinado desde el punto de vista jurídico, una institución. Cuando se habla, por ejemplo, de un ius fuendi, se quiere reflejar toda la situación jurídica asociada a la cosa. ${ }^{57}$ Por ello, Guzmán Brito indica que la inclusión del dominio como cosa incorporal tiene su origen en los juristas medievales, quienes discutían la cuestión del usufructo como parte del dominio. En el texto de Paulo, D. 7,1,4 se habla del usufructo como partes del dominio. En otro texto, del mismo autor, se dice exactamente lo contrario (D.50, $16,25 \mathrm{pr}$.). Dedujeron que el usufructo es parte del dominio, en cuanto el dominio contiene algunas de sus facultades, pero que no es parte, en

Tópica, distingue entre las cosas que "son" y aquellas que "no son", porque se entienden. Guzmán Brito menciona otros precedentes, entre los que parece muy relevante el aporte de Quintiliano, quien califica el ius en general como cosa incorporal. Para el autor citado, Gayo va a ser el primer jurista que va a unificar la tradición filosófica, que distinguía entre corporale e incorporale y la jurídica, que distinguía entre los corpora y los iura, elementos todos pueden encontrarse en el patrimonio de un sujeto.

55 Villey, cit. (n. 51), pp. 77, 85; 88-90. Como indica p. 383, Gayo distingue entre aquellas cosas que tienen existencia corpórea, es decir, que se pueden tocar, de aquellas que no tiene tal existencia (según Gayo, quae tangi non possunt, es decir, que no se pueden tocar). Dicha clasificación habría sido tomada de la dialéctica antigua. Del mismo modo, Cicerón había distinguido entre res quae sunt, es decir, cosas que tienen existencia física; $y$, res quae intelleguntur, es decir, cosas que no tienen una existencia física.

${ }^{56}$ D'Ors, cit. (n. 50) pp. 288-289.

57 Villey, cit. (n. 51), pp. 81-85. Con todo, siguiendo a Talamanca, cit. (n. 51), pp. 383-384, la distinción gayana adolece de cierta incongruencia, porque tanto el dominio como los otros derechos reales son figuras jurídicas, que tienen o pueden tener como objeto una cosa; cuando esa cosa tiene un sentido jurídico, es una cosa incorporal. 
el sentido de que no es especie del dominio, sino que ambos son especies del derecho real. ${ }^{58}$

Por otro lado, si se considera que, en definitiva, en la época justinianea se encontraba ya desarrollada la idea de derecho subjetivo, uno debiese esperar que en las Instituciones de Justiniano hubiese un desarrollo distinto de la idea de las cosas incorporales y, en general, del ius, apareciendo ahora como una potestad o facultad, antes que como la cosa misma, que se examina desde el reflejo de la juridicidad. Una declaración en el sentido que apuntamos proporciona Justiniano en las sus Institutas, 1, 2, 12: "Omne

${ }^{58}$ GuZMÁn Brito, cit. (n. 6), p. 497. Véase también Grossi, Paolo, La proprietà e le proprietà nell'officina dello storico, en Quaderni Fiorentini per la storia del pensiero giuridico moderno, 17, (1988), pp. 402-403. Tan identificado está el dominio con la cosa corporal, que sobre la cosa incorporal Gayo, en sus Comentarios al Edicto provincial expresa la opinión de que sobre las cosas incorporales no puede haber entrega, ni usucapión (D. 41, 1, 43, 1: "Incorporales res traditionem et usucapionem non recipere, manifestum est"). Tampoco puede haber, según Paulo, Comentarios al Edicto, posesión (D. 41, 2, 3pr.: "Possideri autem possunt, quae sunt coporalia). En el proyecto de 1853, Bello había regulado el dominio, la tradición y la posesión, con mayor apego al pensamiento romano. El artículo 688 del proyecto declaraba: "Se concibe también sobre las cosas incorporales una especie de propiedad, que se llama cuasidominio" (hoy, como se sabe, el artículo 583 dispone: "Sobre las cosas incorporales hay también una especie de propiedad"). Correlativamente, el artículo 828 del referido proyecto, senalaba que: "Las cosas incorporales no admiten tradición verdadera; pero hace veces de tradición el ejercicio del derecho por una parte y la ciencia y paciencia del ejercicio por la otra". No hay en el Código actual una regla similar, pero es sintomático que mientras la definición de tradición en el proyecto decía que se trataba de un modo de adquirir el dominio de cosas corporales; el actual artículo 670 dispone que la tradición es un modo de adquirir el dominio de las cosas (y sabemos que, entre las cosas, hay corporales e incorporales). Finalmente, el artículo 858 del proyecto contemplaba una cuasiposesión para las cosas incorporales, con las mismas calidades y vicios que la posesión sobre cosa corporal. Los actuales artículos 700 y 715 modificaron el sistema. El primero no define la posesión como la tenencia, con ánimo de dueño, de una cosa corporal (como lo hacía el proyecto en el artículo 830), sino de tenencia de cosas; a su turno, el artículo 715 ya no se refiere a la cuasiposesión, sino a la posesión, con las mismas calidades y vicios de una cosa corporal. Véase Bello, Andrés, Obras completas: Proyecto de Código Civil (Santiago, Nascimento, 1932), t. II. El proyecto inédito, por su parte, contiene normas idénticas a nuestros actuales disposiciones en la materia que analizamos. El 688 es equivalente al actual artículo 583; el artículo 806, al actual artículo 670, para la tradición (con la interesante diferencia de que, mientras el artículo 806 dispone que lo que se dice del dominio, se extiende a la propiedad de las demás cosas incorporales; el actual artículo 670 dispone que lo que se dice del dominio se extiende a los otros derechos reales); los artículos 822 y 823 , a los artículos 682 y 683; el artículo 830, al actual artículo 700 (la posesión es la tenencia de una cosa y no de una cosa corporal), entre otras. Véase Bello, Andrés, Obras completas: Inédito (Santiago, Nascimento, 1932), t. III. 
autem ius, quo utimur, vel ad personas pertinet, vel ad res, vel ad actiones. Et prius de personis videamus. Nam parum est ius nosse, si personae, quarum causa constitutum est, ignorentur" " "Todo el derecho de que usamos, se refiere $o$ a las personas, o a las cosas, o a las acciones. Tratemos primero de las personas. Porque es poco haber conocido el derecho, si se desconocen las personas por cuya causa se ha constituido").

Sin embargo, tanto Gayo, como Justiniano, definen y se refieren a las cosas incorporales de un modo similar. Según Justiniano, 2, 2, 3: "Incorporalis autem sunt, quae tangi non possunt, qualia sunt ea, quae in iure consistunt: sicut hereditas usufructus obligationes quoquo modo contractae". ${ }^{59}$ En tanto Gayo 2, 14 indica: "Incorporalis sunt, quae tangi non possunt, qualia sunt ea, quae <in> iure consistunt, sicut hereditas usufructus obligationes quoquo modo contractae ${ }^{60}$ En otro lugar hemos propuesto que la expresión in iure consistunt no admite sólo la traducción: "las que consisten en un derecho", 61 sino más propiamente: "las que provienen del Derecho", es decir, que tienen una existencia ideal. ${ }^{62}$

\section{V. ¿CUÁl ES EL CONTENIDO DEL DOMINIUM ROMANO?}

Hoy día tenemos la idea muy acentuada de que el dominio puede explicarse por y desde su naturaleza de derecho real. Ya hemos visto que este enfoque no cuadra con el origen y la naturaleza de cosa corporal, pero además, también nuestra tendencia es pensar en el dominio como la suma de facultades. Si bien es cierto no puede hablarse de derecho real, en sentido estricto en el Derecho romano, podríamos considerar que las facultades descritas en la definición de dominio del Código civil, pueden ser identificadas en Roma. Pero además uno podría avanzar la siguiente pregunta: ¿representan estas facultades la esencia del dominio o hay que encontrar dicha esencia en otro lugar?

No cabe duda de que prima facie el dominio romano comprende una relación de fuerza, de poder sobre la cosa. Ello queda claro en la relación

59 Para las Institutas de Justiniano, hemos seguido el texto de Krueger, Paul, Institutiones (15a edición, Berolini, 1928).

${ }^{60}$ Para el texto en latín de las Instituciones de Gayo, hemos seguido la publicación Huchke, Eduardo, Gai Institutionum. Commentarii Quattuor (2a edición, Lipsiae, 1908), y también el de SAMPER, Francisco, Instituciones Jurídicas de Gayo (Santiago-Mexico-Barcelona-Buenos Aires, 2000) p. 93.

${ }^{61}$ Aunque esta ha sido la lectura tradicional. Por ejemplo, véase AmunÁteguI, cit. (n. 4), p. 516: "No debemos olvidar que la corporalidad o incorporalidad de una cosa depende de si esta es un derecho o no".

${ }^{62}$ Nos referimos a nuestro artículo Aedo Barrena, Cristián, Obligatio: in iure consistunt, en Revista Chilena del Derecho 40, № 3, (2013). 
que Gayo 4, 16 hace de la actio sacramentum in rem. La declaración que debía hacer cada contendor se realizaba con una lanza, en representación de la occupatio bellica, la forma de adquisición de la propiedad que los romanos consideraron originaria. ${ }^{63}$ Probablemente, de acá deriva la idea de que las potestades del dueño constituyen una cosa corporal, es decir, se confunden con la cosa sobre las que se ejercen las facultades.

Ahora bien, reflexionemos sobre las facultades del dominium. Aunque no podemos hablar de derecho real, los romanos conocieron potestades o facultades asociadas al dominio, aunque, como indica Samper, estas facultades se identificaban con la cosa y reflejaban las posibilidades de aprovechamiento de la misma. ${ }^{64}$ Dichas facultades eran: a) uti o uso reiterado de las cosas no consumibles; b) frui, el aprovechamiento de los frutos, sin agotar la cosa en su substancia y según su destino natural; c) habare o abutendi, la facultad de disposición, tanto material, como jurídica (mediante la enajenación).

Podríamos preguntarnos si dichas facultades constituyen la esencia del dominio. ${ }^{65}$ Si ello es así, deberíamos esperar que sin ellas, no existiera dominio y, más importante para el análisis a nuestro juicio, que no se reconocieran dichas facultades en otra institución. La cuestión es que -y esta reflexión vale tanto para el Derecho romano, como para el chileno-, no puede ser definido el derecho de dominio en función de las facultades, no porque necesitemos una definición sintética, desde el punto de vista dogmático. Por el contrario, a nuestro juicio, la definición del Código civil chileno, aunque no lo diga directamente, ha respetado la tradición romana en el sentido que se analizará.

Si uno piensa en el poseedor civil, es decir, aquél que ha adquirido una

${ }^{63}$ Capogrossi, cit. (n. 11), p. 188; Talamanca, cit. (n. 27), p. 389.

${ }^{64}$ SAMPER, cit. (n. 42), p. 113.

${ }^{65}$ Miceli, cit. (n. 13), p. 259 entiende que probablemente la evolución de la propiedad no la despojó de su estructura esencial, a saber, que se trataba de un poder omnicomprensivo y soberano, no de carácter netamente económico, desarrollándose en el período clásico una mayor especificación del concepto de dominio frente a otras figuras. Véase una lectura distinta para la estructura esencial de la propiedad en LinAZASORo, cit. (n. 51), pp. 254-256. Para este autor, la esencia del dominio está representada por el valor económico de la cosa sobre la que recae la propiedad, puesto que, siguiendo las ideas de Lhumann en esta parte, concluye que el dinero determina el contenido esencial de la propiedad: "De lo señalado se deduce claramente que la garantía intocable por el legislador en lo que se refiere al derecho de propiedad, y de consecuencia, su contenido esencial, lo constituye el valor y no la materialidad de la cosa en si misma, el dinero que es parte de la cosa. Esto, es en los términos de Luhmann, que ya no se puede interpretar el dinero partiendo de la propiedad, sino que es necesario efectuarlo en sentido inverso; es decir, interpretar la propiedad a partir del dinero". 
cosa con justa causa (o, lo que hemos examinado antes como propiedad bonitaria), ${ }^{66}$ que sabemos se encuentra en una situación de hecho, debemos preguntarnos, ¿qué puede hacer éste frente a la cosa?. En otras palabras, ¿puede el poseedor usar, gozar y todavía enajenar la cosa? Ciertamente, en el sistema que modernamente se ha denominado del título y el modo, ello es posible y el adquirente estará en vías de ganar la cosa por usucapión. Y, entonces, ¿en qué queda la posición del propietario, sino se encuentra en sus facultades? A nuestro juicio, el sistema romano contesta esta cuestión desde el procedimiento: el dueño es tal -y aquí está su esencia- porque puede reclamar la posesión de la cosa con exclusividad. ${ }^{67}$ Debe recordarse que ésta se dirige por el dueño no poseedor, contra el poseedor no dueño, precisamente para reclamar la posesión exclusiva. ${ }^{68}$ Las facultades, por tanto, están asociadas a la posesión, no al dominio. Como magníficamente expresa Amunátegui, a propósito de los interdictos posesorios: "En efecto, la posesión consiste básicamente en la detentación material de la cosa, la cual se traduce en el ejercicio de actos posesorios en ella, es decir, de actividades donde de hecho se ejerzan las facultades del dominio, sean de uso, goce o disposición. Turbar la posesión no es sólo despojar al detentador del bien, sino también impedirle de hecho el ejercicio de dichos actos posesorios". ${ }^{69}$ Como expresa Peñailillo, a propósito de las relaciones posesión y dominio, éste último trae consigo, como consecuencia necesaria, el derecho a poseer, que bien a ser el ejercicio mismo del dominio. Así, el dueño, en palabras de Peñailillo es un poseedor con derecho a poseer. ${ }^{70} \mathrm{Y}$, como dice Savigny:

${ }^{66}$ Como indica SAmper, cit. (n. 42), p. 123, ésta se presenta como la justa apariencia de dominio que habilita para adquirir las cosas por usucapio.

${ }^{67}$ Que el dueño tenga la facultad de poseer exclusivamente, queda claro en el tratamiento de la acción reivindicatoria. El dueño no reclama facultades, sino la posesión que en los hechos le permitirá ejercerlas. Véase, por ejemplo, el pasaje D. 6, 1, 62, 1: "Generaliter autem, quum de fructibus aestimandis quaeritur, constat animadverti debere, non an malae fidei possessor fruiturus sit, sed an petitor frui potuerit, si ei possidere licuisset; quam sententiam Iulianus quoque probat" "Pero generalmente, cuando se trata de estimar los frutos, es sabido que debe atenderse, no a si los haya de disfrutar el poseedor de mala fe, sino a si habría podido disfrutarlos el demandante, si se le hubiere permitido poseer; cuya opinión aprueba también Juliano').

${ }^{68}$ Véase la explicación de D’Ors, cit. (n. 6), pp. 199-202.

69 AmunÁtegui, cit. (n. 21), p. 106. En el mismo sentido, GuZmán Brito, cit. (n. 6), p. 534, indica: "Es en tal sentido que en su momento dijimos que el dominio como Derecho ampara, aparte del uso, el disfrute y la disposición, también la tenencia de la cosa. Ahora estamos en condiciones de entender que esa tenencia quiere decir en realidad posesión, porque se trata precisamente de la tenencia del dueño en que aquélla consiste".

${ }^{70}$ Peñailillo, cit. (n. 2), p. 332. 
“...el propietario tiene el derecho de poseer; este mismo pertenece a aquél que tiene la posesión del propietario: ninguna otra persona tiene ese derecho". ${ }^{71}$

La posesión es, como señalan las fuentes, siguiendo a Burdese, siempre una situación de hecho, por diferencia con la situación jurídica que supuso amparar el dominium. Siguiendo al autor, algunos pasajes como D. 41, 2, 1, 3, (“...eam enim rem facti, non iuris esse...") o D. 4, 6, 19 (“...possessio autem plurimum facti habet...") indican claramente el carácter factual de la posesión, que queda entonces de algún modo incorporada, podríamos decir, en el concepto del dominio. ${ }^{72}$

La idea de que entre domino y posesión existe una íntima relación, ya había sido puesta en evidencia por Ihering. En el pensamiento de Ihering, la posesión se tradujo en la posición avanzada de la propiedad, porque de ordinario el poseedor lo era. Así, el origen las acciones posesorias (es decir, los interdictos posesorios), se encontraría en la protección de la posesión, como exteriorización de la propiedad. La posesión, según Ihering, era el ejercicio de la propiedad o, al menos, de una propiedad probable o presunta. De este modo, se producía una facilitación de la prueba para el propietario, pero, como consecuencia indeseada, el Derecho romano debió ceder en la protección de un poseedor no propietario. ${ }^{73}$

${ }^{71}$ Savigny, Tratado de la posesión según los principios del Derecho romano (Madrid, Imprenta de la Sociedad Literaria y Tipográfica, 1845), p. 6. Como señala ArANGIO-Ruiz, cit. (n. 54), p. 179: "Con ciò si trascurava quella facoltà che, dal punto di vista giuridico, costituisce l'elemento più saliente della proprietà: cioè l'esclusione di qualunque ingerenza di terzi in ordine alla cosa".

72 Véase Burdese, Alberto, Possesso (Diritto romano), en Enciclopedia del Diritto (Milano, Giuffrè, 1985), t. XXXIV, p. 453. Y; en la clásica concepción romana, esa posesión requirió de corpus y animus, como lo indica el pasaje de Paulo, D. 41, 2, 3, 1: "Et adipiscimur possessionem corpore et animo, neque per se animo, aut per se corpore". Anotemos que, en todo caso, el concepto de possessio tampoco fue unitario. Frente a la possessio civil, que correspondía al dueño, los juristas clásicos protegieron al poseedor pretorio, mediante interdictos. Para esta cuestión, D'Ors, cit. (n. 6), pp. 192-198. También se distinguió, claramente, entre posesión civil (es decir, posesión como dueño, aunque no lo sea), de la posesión natural (mera detentación de la cosa). Véase GuZmán Brito, cit. (n. 6), p. 533 y D. 41, 5, 2, 1.

${ }^{73}$ Véase la clásica obra Von IHERING, Rodolfo, La posesión (trad. de Adolfo Posada, 2a edición, Madrid, Reus, 1926), pp. 91-95; 100-101; 113. Aunque no puedan aceptarse todas las consecuencias de la tesis de Ihering, no cabe duda que la perspectiva ofrecida resulta interesante, no obstante pueda reprochársele cierto unilaterialismo, como hace Díez-Picazo, Luis, Fundamentos del Derecho Civil Patrimonial, t. III: Las relaciones jurídico reales. El registro de la propiedad. La posesión (Madrid, Civitas-Thomson-Reuters, 2008), p. 629, por cuanto el poseedor es protegido en ausencia del dominio. La otra consecuencia a la que nos conduce la tesis de Ihering, 
El Digesto contiene varios pasajes que permiten afirmar que el poseedor cuenta con la facultad y puede, en los hechos, disponer de la cosa (por mucho que esa disposición no produzca idénticos efectos a la disposición que hace el dueño), especialmente tratándose de la acción publiciana. Dicha acción se concede a favor del poseedor de buena fe, que no ha usucapido (D. 6, 2, 1, 1 y 2). Es categórico el D.6, 2, 3, 1 en el sentido de que la acción solo corresponde a quien goza de un justo título y ha adquirido de buena fe. ${ }^{74}$ En el mismo sentido, reiteran la exigencia de una justa causa y de buena fe, el pasaje del D. 6, 2, 7, 11. ${ }^{75}$ Pero además de la adquisición de la cosa con buena y justo título, para gozar de la acción publiciana, debía haberse recibido la cosa por tradición. Así lo señala expresamente el pasaje del D. 6, 2, 7, 16: "Ut igitur publiciana competat, haec debent concurrere, ut et bona fide quis emerit, et ei res emta eo nomine sit tradita. Ceterum ante traditionem, quamvis bonae fidei quis emtor sit, experiri Publiciana non poterit" ("Asi, pues, para que competa la acción Publiciana, deben concurrir estas circunstancias, que alguien haya comprado de buena fe, y que por tal título le haya sido entregada la cosa comprada. Por lo demás, antes de la tradición, aunque alguien sea comprador de buena fe, no podrá ejercer la acción Publiciana”). Y, todavía más claro en este sentido, el pasaje D. 6, 2, 7, 17: "Iulianus libro séptimo Digestorum scripsit, traditionem rei emtae oportere bona fide fieri; ideoque si sciens alienam possessionem apprehendit, Publiciana eum expederi non posse, quia usucapere non poterit. Nec quisquam putet, hoc nos existimare, sufficere initio traditionis ignorasse rem alienam, uti quis possit Publiciana experiri, sed oportere et tunc bona fide emtorem esse"

es que la esencia de la posesión no reposa en el ánimo. Véase aquí la polémica entre IHering, cit. (n. 73) pp. 189 y ss., contra la idea de SAVIGNY, cit. (n. 71), pp. 5 y ss.

${ }^{74}$ Según el pasaje: "Ait Praetor: "ex iura causa petet"; qui igitur iustam causam traditionis habet, utitur Publiciana. Et non solum emtori bonae fidei competit Publiciana, sed et aliis, ut puta ei, cui dotis nomine tradita res est, necdum usucapta; est enim iustissim causa, sive aestimata res in dotem, data sit, sive non. Item si res ex causa iudicati sit tradita" "Dice el Pretor: "pidiere por justa causa"; por consiguiente, el que tiene justa causa de la entrega, usa la Publiciana. Y compete la Publiciana no solo al comprador de buena fe, sino también a otros, como, por ejemplo, a aquel a quien se entregó la cosa a título de dote y aun no fue usucapida; porque es causa muy justa, ora habiendo sido estimada, ora no, haya sido dada la cosa en dote. Igualmente si la cosa hubiera sido entregada por causa de los juzgado").

75 "Praetor ait: "qui bona fide emit"; non igitur omnis emptio proderit, sed ea, quae bonam fidem habet. Proinde hoc sufficit, me bonae fidei emptorem fuisse, quamvis non a domino emerim, licet ille callido consilio vendiderit; neque enim dolus venditoris mihi nocebit" "Dice el Pretor: "el que compró de buena fe"; así, pues, no aprovechará toda compra, sino la que se tiene de buena fe. Por lo cual basta esto, que yo haya sido comprador de buena fe, aunque haya comprado al que no era dueño, por más que él hubiere vendido con ánimo de engañar; porque no me perjudicará el dolo del vendedor"). 
("Escribe Juliano en el libro séptimo del Digesto, que debe hacerse de buena fe la tradición de la cosa comprada; y que por tanto, si sabiendo uno que era ajena tomó la posesión, no puede él ejercitar la acción Publiciana, porque no podrá usucapir. Y no juzgue nadie que estimamos esto, que basta que al principio de la tradición haya ignorado que la cosa era ajena, para que pueda uno ejercitar la acción Publiciana, sino que corresponde que también entonces sea comprador de buena fe").

En suma, el poseedor de la cosa, no siendo dueño, puede transferir la cosa (hace tradición), aunque sus alcances son distintos, según sea dueño o no. Como dice Ulpiano, Comentario a Sabino, libro XXIX, en el pasaje del D. 41, 1, 20pr.: "Traditio nihil amplius transferre debet vel potest ad eum, qui accipit, quam est apud eum, qui tradit. Si igitur qui dominium in fundo habuit, ad eum, qui accipit, nibil transfert" " $L a$ entrega no debe ni puede transferir al que recibe nada más que lo que hay en poder del que entrega. Si, pues, uno tuvo el dominio sobre un fundo, lo transfiere al entregarlo; y si no lo tuvo, no transfiere nada al que lo recibe'). Y también Papiniano, Cuestiones, en D. 41, 3, 44, 1 dice: "Constat, si rem alienam scienti mibi vendas, tradas autem eo tempore, quo dominus ratus habet, traditionem tempus inscipiendum, remque meam fieri" ("Es sabido, que si me vendieras una cosa sabiendo yo que era ajena, pero me la entregaras al tiempo en que su dueño lo ratifica, se ha de atender al tiempo de la entrega, y la cosa se hace mia"). ${ }^{76}$

Recordemos que causas de la posesión, como "pro emptore" o "pro donatio", "pro soluto" suponen traditio de la cosa. ${ }^{77} 78$ La posesión requiere,

${ }^{76}$ Muchos pasajes expresan la idea de que la traditio cumple papeles diferenciados, según si el tradente es o no dueño. La adquisición de una cosa ajena permite ganar por usucapio, con lo que la posesión importa tradición. Véase D. 41, 3, 33, 1 (Juliano, Digesto, libro XLIV); D. 41, 3, 44, 4 (Papiniano, Comentarios); D. 41, 4, 2, 21 (Paulo, Comentarios al Edicto).

${ }^{77} \mathrm{La}$ exigencia de la traditio para la adquisición de la posesión pro emptore, Paulo, Comentarios al Edicto, D. 41, 4, 2pr. Como indica GuZMÁn Brito, cit. (n. 6), p. 544, el cumplimiento de la obligación de entregar del vendedor al comprador, no puede considerarse como causa pro soluto, porque la obligación del vendedor no es de dar (hacerlo dueño), sino de entregar (por tanto, obligación de hacer) y no cabe, en consecuencia, la solutio. Para la posesión pro donatio, claramente el pasaje de Paulo, Comentarios al Edicto, D. 41, 1, 6, 1 pr.

${ }^{78}$ Hay que advertir, en todo caso, que la causa de la posesión, especialmente la denominada por los juristas "pro suo", debe separarse de la buena fe exigida para la usucapión. Por eso, aunque queremos explorar las relaciones entre traditio y posesión, cabe la advertencia de GUZMÁn Brito, cit. (n. 6), p. 542, en orden a que la causa de la posesión no puede analizarse de modo conjunto con la cuestión de la usucapión, porque dicha causa debe existir sea que el poseedor pueda o no usucapir. Sobre esta materia, es ilustrativo, a nuestro juicio, el texto de Paulo, Comentarios al Edicto, D. 41, 4, 2, 1: "Separata est causa possessionis et usucapionis; nam vere dicitur 
como sabemos, cuerpo y ánimo para adquirirla (D. 41, 2, 3, 1). ${ }^{79}$ Desde esta perspectiva, la traditio aparece íntimamente ligada al sistema de la adquisición de la posesión. La traditio real podía significar la adquisición, tanto del corpus, como del animus. De este modo, tanto se perdía para el tradens, como se adquiría por quien recibía la cosa. ${ }^{80} \mathrm{Y}$, por razones prácticas, dicha adquisición importó el desarrollo de formas fictas de traditio, como la traditio longa manu o la traditio brevi manu, hipótesis en que la tradición se efectuaba solo animo. ${ }^{81}$

Aunque con ciertas diferencias entre el régimen romano y sistema codificado chileno, nadie puede poner en duda que en esencia, el esquema aquí presentado es el mantenido en el Código de Bello, en el sentido de que la tradición opera, bien en la adquisición del dominio y pone al propietario en posesión (causa de la posesión en términos romanos), bien coloca al adquirente en calidad de poseedor, lo constituye como tal y permite ganar la cosa por prescripción (artículos 670, 671, 682, 683 y 702, entre otros). ${ }^{82}$ Es opinión unánime, por tanto, que el poseedor pueda, en los hechos,

quis emisse, sed mala fide, quemadmodum qui sciens alienam rem emit, pro emtore possidet, licet usu non capiat" ("La causa de la posesión es distinta de la de la usucapión; porque se dice con verdad que uno compró, pero con mala fe, a la manera que posee como comprador el que a sabiendas compró cosa ajena, aunque no la usucapirá').

79 "Et adipiscimur possessionem corpore et animo, neque per animo, aut per corpore". Véase también D. 41, 2, 3, 3.

${ }^{80}$ Véase especialmente D. 41, 2, 3, 9: "Et si alii tradiderim, amitto possessionem; nam constat, possidere nos, donec aut nostra voluntate discesserimus, aut vi deiecti fuerimus"

${ }^{81}$ Véase D. 41, 2, 18, 2 y D. 46, 3, 79, para la traditio brevi manu; D. 41, 1, 9, 5, para la longa manu.

${ }^{82}$ Con todo, la precisión terminológica reviste consideración. Pudiera pensarse que la disposición equivale a tradición. Tomemos nota de un ejemplo. Peñailillo, cit. (n. 2), p. 137, nos dice que el dueño dispone jurídicamente cuando celebra negociaciones sobre la cosa (arrendamiento, comodato) o la grava (con prenda o hipoteca) o la transfiere a un tercero; en cambio, AlESSANDri, SOMARRIVA y VODANOVIC, cit. (n. 2), t. I, p. 54, nos señalan que la facultad de disposición y, por tanto, la enajenación, supone transferir el dominio a otro. Ello querría decir que el poseedor, en estricto rigor, no podría disponer, si por ello se entiende transferir el dominio y no de modo más general, como consideramos más adecuado, de hacer la tradición. En efecto, pensar en la disposición como equivalente a la transferencia del dominio supone el problema de que, para que ello ocurra, el tradente debe ser dueño; luego, el adquirente deberá demostrar, además de la tradición, que quien le hizo la tradición era dueño, pero la condición de dueño del tradente también supone que éste, a su vez, recibió de un sujeto que era dueño. Por ello, la traditio en nuestro sistema prueba de modo inmediato la posesión y no el dominio. Configurado así el sistema, parecería más razonable pensar que la disposición de una cosa debe interpretarse como la posibilidad (revestida de facultad o no), de hacer la tradición; en otras palabras, que 
hacer tradición de la cosa y disponer de ella, aunque con efectos distintos. ${ }^{83}$ Lo que decimos no puede resultar extraño. Aunque aparentemente puede disponer del derecho real (en este caso, del dominio), sólo el titular, en la doctrina viene discutiéndose desde hace tiempo la denominada facultad de disposición como un quid diferenciado del derecho subjetivo, que puede tener una significación autónoma (precisamente, en los casos, por ejemplo, de transferencia realizada por un tercero).$^{84}$

Un último apunte antes de ensayar nuestras conclusiones. Habíamos dicho que Ihering es quien apunta la íntima relación propiedad y posesión. Dicha conexión se prueba, en concepto de Ihering, entre otras, por esta premisa: donde no puede haber propiedad, no puede haber posesión. ${ }^{85}$ Nuestro Código civil, con algunos matices, sigue un criterio similar. Desde un punto de vista subjetivo, el artículo 723 repite las reglas generales de capacidad, idénticas a las del dominio. ${ }^{86}$ Desde el punto de vista objetivo,

disponer significa transferir, como sinónimo de hacer tradición, sea el tradente dueño o no de la cosa y cumpliendo, en tales casos la tradición, papeles diferenciados.

Sin perjuicio de todo ello, debemos tener presente que el Código, a propósito de la posesión, hace sinónimas las voces tradición y enajenación. En efecto, el Código no tiene problema alguno para admitir que el poseedor pueda enajenar, tenga o no el dominio sobre la cosa. Veamos algunas normas. El artículo 704 № 3, dispone: "No es justo título: $3^{\circ}$ El que adolece de un vicio de nulidad, como la enajenación que debiendo ser autorizada... "; el artículo 728 prescribe: "Para que cese la posesión inscrita, es necesario que la inscripción se cancele, sea por voluntad de las partes, o por una nueva inscripción en que el poseedor inscrito transfiere su derecho a otro, o por decreto judicial"; finalmente, el artículo 730: "Si el que tuene la cosa en lugar y a nombre de otro, la usurpa dándose por dueño de ella, no se pierde por una parte la posesión ni se adquiere por otra; a menos que el usurpador enajene a su propio nombre la cosa".

${ }^{83}$ Por todos, Peñailillo, cit. (n. 2), pp. 225-227. El artículo 841 del proyecto de 1853 disponía: "Para que la tradición produzca posesión civil, no es necesario el dominio del tradente, con tal que posea, a lo menos naturalmente; pero se requieren todas las otras condiciones expresadas en el título precedente". La posesión civil, equivalente a nuestra actual posesión regular, era la que procedía de justo título y buena fe, como lo dispone ahora el artículo 702. Véase, BELLo, cit. (n. 57), t. II, p. 202.

${ }^{84}$ Sobre este problema, véase DíEZ-PiCAZO, cit. (n. 73), pp. 947-948.

${ }^{85}$ IHERING, cit. (n. 73), pp. 173-183.

${ }^{86}$ Véase Peńailillo, cit. (n. 2), p. 369. La norma parece decir lo contrario, pero no hace sino consagrar capacidad de goce, versus de ejercicio. Si la posesión no estuviese tan íntimamente vinculada al dominio, tales limitaciones carecería de sentido, porque lo que se hace no es sino exigir capacidad de enajenación. Con todo, hay varias normas que permiten también arribar al fundamento de la necesidad de capacidad en la posesión: el artículo 702, cuando exige tradición si el título es traslaticio de dominio, supone capacidad de enajenación; el artículo 704 No 3 dispone que el título es injusto cuando la cosa ha sido enajenada por un incapaz, sin la autorización del representante legal o de la justicia, según los casos, entre otras disposiciones. 
las cosas susceptibles de posesión son aquellas susceptibles de dominio. ${ }^{87}$ La conexión refuerza a nuestro juicio el argumento de que la posesión se presenta como el contenido esencial del dominio. Desde luego, ello no supone una confusión entre ambos, pero la capacidad y la exigencia de cosas apropiables para la posesión carecen de sentido si la posesión no está vinculada al ejercicio del dueño.

\section{CONCLUSIONES}

La explicación que se ha ensayado en este artículo persigue determinar la importancia del estudio del origen romano del dominio. En una buena medida, consideramos, la importancia queda justificada porque como se ha propuesto, la esencia del concepto de dominio ha permanecido desde su configuración en el Derecho romano.

Las definiciones de dominio que se han incorporado a las codificaciones, adoptan la mirada racionalista de la que se han nutrido los códigos, visualizando el dominio ahora como derecho subjetivo. Las codificaciones, en efecto, como la chilena, recogerán las ideas de los autores franceses del antiguo Derecho, las influencias humanistas y racionalistas; ${ }^{88} \mathrm{y}$, de otra, los ideales de la burguesía liberal del siglo XIX ${ }^{89}$ Y siguiendo a Gómez Arboleya, el tercer elemento, como componente político de la conformación

87 Peñailillo, cit. (n. 2), pp. 334-335. Además de que la definición del artículo 700 exija que la cosa sea determinada, Peñailillo entiende que no puede haber posesión si la cosa no es apropiable. En el mismo sentido, AlesSAndri, Somarriva y VodanOvic, cit. (n. 2), t. I, p. 367.

${ }^{88}$ Para la idea de codificación como hija de la filosofía iusnaturalista véase, FiloMUSI GUELFI, Francesco, La codifizione civile e le idee moderne che ad essa si riferiscono, en DEL VeCCHIO, Giorgo (a cura di), Lezioni e saggi di Filosofia del diritto (Milano, Giuffrè, 1949), pp. 185-188 y HaLpérin, Jean Louis, L'impossible Code Civil (Paris, PUF, 1992), p. 55.

${ }^{89}$ Según la idea predominante, las codificaciones fueron hijas de los ideales de la burguesía decimonónica, que introdujo el liberalismo económico y la economía capitalista. Sobre esta cuestión véase TomÁs y VAliente, Francisco, La Codificación. De utopía a técnica vulgarizada, en Michelena Elissalt, Luis y Melena L., José (coordinadores) Symbolae Ludovico Mitxelena septuagenario oblatae (Vitoria-Gasteiz, Universidad del País Vasco, 1985), p. 1485 y Gómez Arboleya, Enrique, El racionalismo y los Códigos europeos. Primera parte, en Revista de Estudios Políticos, 57, (1951), pp. 451-452. En el mismo sentido, Roca Guillamon, Juan, Codificación y crisis del Derecho civil, en AA.VV. Centenario del Código Civil (1889-1999) (Madrid, Editorial Centro de Estudios Ramón Areces, 1990), t. II, pp. 1760-1763, enfatizando el carácter individualista del pensamiento burgués. 
de los códigos, fue el Estado nacional. ${ }^{90}$ Pero este flujo de ideas no hicieron otra cosa que recoger en esencia las instituciones del Derecho romano. ${ }^{91}$

Visto así, el concepto de dominio en el Derecho romano se nos presenta como un modelo de análisis, que nos permite reflexionar sobre la sustancia y no atender solamente a la consagración normativa. ${ }^{92}$

${ }^{90}$ Gómez Arboleya, cit. (n. 89), pp. 450-451. El Estado moderno, señala este autor, quiere imponer su forma, mandar con raciocinio. Los territorios bajo los cuales está establecido deben ser regulados por la unidad de espíritu: el espíritu de la ley. Véase, en el mismo sentido, Astuti, Guido, La codificazione del Diritto Civile, en AA.VV. La formazione storica del Diritto moderno in Europa. Atti del Terzo Congreso Internazionale della Società Italiana di Storia del Diritto (Firenze, Olschki, 1977), t. II, pp. 852-853.

${ }_{91}$ Podríamos agregar, siguiendo a CARONI, Pio, Lecciones catalanas sobre historia de la codificación, trad. por Aquilino Iglesia Ferreirós (Madrid, Marcial Pons, 1996), pp. 34-37, que el impulso final de la codificación vino de la mano de la Ilustración. En lo que el autor denomina el "giro ilustrado", se acentuarán las ideas que buscaban la superación del ius commune, pues aún con los nuevos elementos incorporados en él, la base de todo ese sistema se encontraba en el Derecho romano. Como indica Caroni, corrientes contrapuestas trabajaron en este afán: de un lado, el absolutismo (deseoso de suprimir cualquier fuente del Derecho distinta de la ley, emanada del monarca); de otro, los ilustrados con sus afanes emancipadores. Caroni habla entonces de dos animas, una estatalista y otra garantista.

${ }^{92}$ En este sentido, véase Miceli, cit. (n. 13), p. 263. En otro trabajo deberá enfrentarse la cuestión del concepto de la propiedad y la tierra para las culturas indígenas, que no necesariamente obedecen al modelo europeo importado desde la colonización y profundizado por la uniformación del Derecho nacional, mediante la codificación. Para esta cuestión, véase GonZÁlez CorTéz, Héctor y GundermanN KRÖLL, Hans, Acceso a la propiedad de la tierra e identidades colectivas entre los aymaras del norte de Chile (1821-1930), Chungará, en Revista de Antropología Chilena, vol. 41, No 1, (2009), pp. 51-70. 
